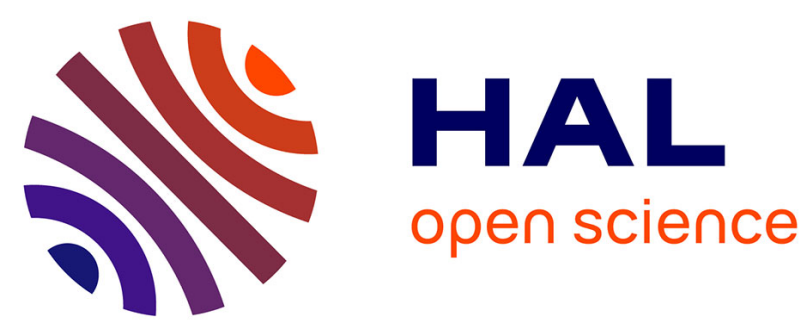

\title{
Underground renewal time and mixing of the main mineral waters of Tunisia: A multi-tracer study
}

Philippe Jean-Baptiste, Elise Fourré, Elyès Gaubi, B. Minster, Luc Aquilina, Thierry Labasque, J.L. Michelot, Marc Massault, Abdallah Ben Mammou

\section{- To cite this version:}

Philippe Jean-Baptiste, Elise Fourré, Elyès Gaubi, B. Minster, Luc Aquilina, et al.. Underground renewal time and mixing of the main mineral waters of Tunisia: A multi-tracer study. Applied Geochemistry, 2017, 85 (Part A), pp.10-18. 10.1016/j.apgeochem.2017.08.006 . insu-01578508

\section{HAL Id: insu-01578508 \\ https://hal-insu.archives-ouvertes.fr/insu-01578508}

Submitted on 29 Aug 2017

HAL is a multi-disciplinary open access archive for the deposit and dissemination of scientific research documents, whether they are published or not. The documents may come from teaching and research institutions in France or abroad, or from public or private research centers.
L'archive ouverte pluridisciplinaire HAL, est destinée au dépôt et à la diffusion de documents scientifiques de niveau recherche, publiés ou non, émanant des établissements d'enseignement et de recherche français ou étrangers, des laboratoires publics ou privés. 
Underground renewal time and mixing of the main mineral waters of

3
P. Jean-Baptiste ${ }^{1}$, E. Fourré ${ }^{1}$, E. Gaubi ${ }^{2}$, B. Minster ${ }^{1}$, L. Aquilina ${ }^{3}$, T. Labasque ${ }^{3}$, J.L. Michelot $^{4}$, M. Massault ${ }^{4}$, A. Ben Mammou ${ }^{2}$

${ }^{1}$ LSCE, CNRS-CEA-UVSQ, Centre de Saclay, F-91191, Gif-sur-Yvette, France ${ }^{2}$ Laboratoire Ressources Minérales et Environnement, Univ. Tunis El-Manar, Tunisia ${ }^{3}$ CAREN, Géosciences Rennes, UMR 6118, CNRS-University of Rennes 1, POB 74205, F-35042, Rennes cedex, France.

${ }^{4}$ IDES, UMR 8148, CNRS-University of Paris 11, F-91405, Orsay, France.

\section{Abstract.}

Bottled waters are increasingly popular in Tunisia. Most of them come from groundwaters, thus raising the question of the long-term availability of the mineral groundwater resources. Water collected from production springs or wells of eleven mineral waters of Tunisia among the main commercial brands were analyzed for tritium $\left({ }^{3} \mathrm{H}\right)$, helium-3, SF 6 , CFCs and carbon-14. Tracer-tracer plots indicate that all of the groundwaters of our data set are a mixture of modern rainwater with older groundwater flow waters that are beyond the time-scale of the transient tracers. ${ }^{14} \mathrm{C}$ data suggest that the age of these old waters, which constitute the main water reservoir, is of the order of radiocarbon half-life or more. Most of the studied sites have groundwater renewal times in the range $50-150$ years. For the sites where tracer concentrations are the most diluted by old waters, this value logically increase to several centuries.

Keywords: Groundwater, environmental tracers, renewal time, groundwater dating 


\section{Introduction}

The rapid increase in bottled mineral groundwater production in Tunisia needed to meet consumer demand (110 millions bottles in 1995 and 1.04 billion bottles in 2015 - Office du thermalisme at www.thermalisme.nat.tn) raises the question of the longterm sustainability of this economic sector.

Renewal time of groundwater, which is clearly related to the ratio of the storage volume to the recharge rate, is an important notion regarding vulnerability and sustainability of groundwater resources. Numerical models of groundwater flow can describe accurately the hydrodynamic functioning of a given aquifer, and therefore can give stackeholders and the mineral water industry management important indications to prevent pollution and/or overexploitation of the water resource. However, they require detailed information (e.g. boundary conditions, hydraulic conductivity, porosity, etc...) which are usually not available. As an alternative, the analysis of atmospheric transient tracer concentrations in groundwaters can provide important basic information on their residence time and mixing.

As a development arising from tritium, which can be used as a transient tracer as a result of ${ }^{3} \mathrm{H}$ injection into the atmosphere from the atmospheric testing of nuclear devices in the 50's and early 60's, the ${ }^{3} \mathrm{H}-{ }^{3} \mathrm{He}$ dating method offers a direct measure for the time since groundwater had its last gas exchange with the atmosphere. The ${ }^{3} \mathrm{H}-{ }^{3} \mathrm{He}$ pair is of particular interest because tritium and its daughter helium-3 are assumed to be fully conservative tracers, and also because the ${ }^{3} \mathrm{H}-{ }^{3} \mathrm{He}$ radioactive clock only relies on the in-situ ${ }^{3} \mathrm{H} /{ }^{3} \mathrm{He}$ ratio. Hence, it is independent of the history of tritium input to the aquifer (Schlosser et al., 1988, 1989; Poreda et al., 1988; Solomon et al., 1991, 1993; Stute et al., 1997). 
Like tritium, ${ }^{14} \mathrm{C}$ was also a by-product of atmospheric nuclear tests. Hence, the resultant transient spike in atmospheric ${ }^{14} \mathrm{CO}_{2}$ can also be used as a transient tracer (Stewart, 2012; Baudron et al., 2013).

The CFCs and $\mathrm{SF}_{6}$ methods are based on the direct comparison of the groundwater tracer concentration with the concentration of these tracers in the atmosphere, and hence in groundwater recharge. Because their atmospheric concentration has changed through time, this provides the basis for travel time determination (Thompson and Hayes, 1979; Cook and Solomon, 1995; Busenberg and Plummer, 1992, 2000; Goody et al., 2006; Darling et al., 2012).

Each tracer has its own atmospheric input function and each tracer method relies on its own specific set of assumptions and caveats. There are significant differences in the reliability of the derived tracer ages. Some caveats are the result of hydrogeology. For CFCs and ${ }^{14} \mathrm{C}$ additional uncertainties of the infiltration conditions influence the resulting ages. Therefore the combination of several tracer methods in parallel is highly preferable to the use of a single method (Szabo et al., 1996; Beyerle et al., 1999; Plummer et al., 2001; Corcho Alvarado et al., 2005, 2007; Massmann et al., 2008; Solomon et al., 2010; Mayer et al., 2014; Kralik et al., 2014; Delbart et al., 2014; Battle-Aguilar et al., 2017). Ideally measured tracer concentrations in a groundwater can be matched simply to a particular year of recharge. However, this requires that the groundwater moves as a result of simple piston flow, that is along parallel flowlines from recharge to discharge. In reality, groundwaters are often a mixture of water of different ages due to the complexity of the hydrogeological network and/or the internal structure of the aquifer. One basic way of resolving flow processes is to plot one tracer versus another (see for instance Figure 3 in Darling et 
80

recharge waters and old tracer-free waters are opposite extremes of groundwater behaviour. In most cases however, groundwater flow may be more complicated and one must test a variety of modeled reservoirs connected to each other serially or in parallel with or without dead volumes, cross flow in between or bypass flow (see Ozyurt and Bayari, 2003 and references therein).

Here we report the application of such a multi-tracer approach to a suite of mineral waters of Northern and Central Tunisia among the main commercial brands. The region is characterized by a semi-arid climate with mild wet winters and hot dry summers (monthly average temperatures vary from $10 \pm 1^{\circ} \mathrm{C}$ in January to $28 \pm 2^{\circ} \mathrm{C}$ in August), and relatively low annual rainfall in the range $300 \mathrm{~mm}-600 \mathrm{~mm}$. For this study, we selected eleven bottled water production sites (Table 1), exploiting local aquifers nested in karstified limestone and/or sandstone formations (see Appendix A). Very little is known by the operators concerning the actual extent of their mineral groundwater resources and the sustainability of their business. Comparison of mineral water withdrawal rates and recharge rates estimated from precipitation figures and catchments' surface area shows that the rate of water withdrawal exceeds the present-day recharge rate. This overexploitation of the local mineral groundwater reservoirs may have serious implications in term of water quality and economic consequences for the mineral water industry. Note that the issue of groundwater overexploitation in Tunisia is not restricted to mineral waters: Tunisia, being a semi-arid to arid country, is facing water shortage of increasing severity as a result of population growth, rising living standards and increasing water consumption by the agricultural sector (Frija et al., 2014) 
The present work aims at exploring the potential of the selected suite of transient

104 tracers (tritium/helium-3, SF, CFCs and radiocarbon) to gain insight into the hydrogeological characterization of these different water reservoirs.

\section{Sample collection and analytical methods}

The sampled sites are shown in Fig. 1, and their main characteristics (climatic conditions, elevation, ...) are summarized in Table 1. Groundwaters were analyzed for ${ }^{18} \mathrm{O} /{ }^{16} \mathrm{O}, \mathrm{D} / \mathrm{H},{ }^{3} \mathrm{H},{ }^{3} \mathrm{He},{ }^{4} \mathrm{He},{ }^{20} \mathrm{Ne}, \mathrm{CFCs}(\mathrm{F}-11, \mathrm{~F}-12, \mathrm{~F}-113), \mathrm{SF}_{6}$. and ${ }^{14} \mathrm{C}$. Apart

112 from Marwa-2009 which shows a high neon supersaturation (see below), the

113 samples were taken at the water extraction point (at the well-head for pumped waters

114 and at the capture point for natural springs) so that contact of the water with the

115 atmosphere can be excluded. With the exception of a few tritium/helium and ${ }^{14} \mathrm{C}$ 116 samples taken in October 2009, all the water samples were collected in

117 September/October 2010.

118 CFCs and $\mathrm{SF}_{6}$ samples were collected in air tight stainless steel cells of 30 and

$119500 \mathrm{ml}$ respectively and were analyzed at the University of Rennes (Labasque et al.,

120 2006; Ayraud et al., 2008). The CFC and SF $_{6}$ concentrations were determined by

121 Purge and Trap (PT) extraction and analysed with a gas chromatograph equipped

122 with an electron capture detector (GC/ECD). The uncertainty is $3 \%$ for water 123 equilibrated with the present-day atmosphere for CFC and 5\% for $\mathrm{SF}_{6}$ (see Table 2).

$124 \quad$ Noble gas samples $(\mathrm{He}, \mathrm{Ne})$ were collected using standard refrigeration grade 125 3/8" copper tubes equipped with metal clamps at both ends. ${ }^{3} \mathrm{H}$ samples were 126 collected in $500 \mathrm{ml}$ pyrex bottle, baked at $75^{\circ} \mathrm{C}$ and pre-filled with argon. The tritium 127 and noble gas isotopic analyses $\left({ }^{3} \mathrm{He},{ }^{4} \mathrm{He},{ }^{20} \mathrm{Ne}\right)$ were carried out at LSCE (CEA- 
128 Saclay) with a MAP-215 mass spectrometer using standard procedures. Helium and

129 neon dissolved in the water samples were first extracted under vacuum into sealed

130 glass tubes. The accuracy is $\pm 0.8 \%$ for helium and neon concentrations, and $\pm 0.4 \%$

131 for the ${ }^{3} \mathrm{He} /{ }^{4} \mathrm{He}$ ratio. Water for tritium determination was degassed and stored during

1329 to 12 months to allow for ${ }^{3} \mathrm{He}$ ingrowth. Uncertainty on tritium determination is given

133 in Table 2. Technical details concerning laboratory treatments and analytical

134 methods are available in Jean-Baptiste et al., 1992, 2010.

135 Carbon-14 samples were taken in $500 \mathrm{ml}$ stainless steel cells and analyzed by

136 accelerator mass spectrometry at the French Radiocarbon National facility (CEA-

137 Saclay), with an accuracy between $\pm 0.1 \mathrm{pmC}$ and $\pm 0.2 \mathrm{pmC}$ (see Table 2). Delta ${ }^{13} \mathrm{C}$

138 was measured by IRMS at Paris-Sud University, with an accuracy of $\pm 0.1 \%$.

139 Water for stable isotope analysis was collected in $15 \mathrm{ml}$ glass bottles. Deuterium

140 and oxygen-18 were analysed at LSCE (CEA-Saclay) by laser spectrometry.

141 Uncertainties are $\pm 0.15 \%$ and $\pm 0.7 \%$ ofor oxygen- 18 and deuterium respectively.

143 3. Results

145 Analytical results are shown in Table 2 . Stable isotopes are between $-50.5 \% 0$ 146 and $-31.6 \%$ for $\mathrm{D} / \mathrm{H}$ and between -7.66 and -5.10 for ${ }^{18} \mathrm{O} /{ }^{16} \mathrm{O}$, respectively. The

147 lowest values correspond to the El Kef region and reflect the altitude effect of this 148 more elevated area (altitude $>850 \mathrm{~m}$ - see Table 1) on the water isotopes 149 composition of rainwaters (Ambach et al., 1968; Siegenthaler and Oeschger, 1980).

150 The results are consistent with precipitation isotopic data for northern and central 151 Tunisia represented by the Tunis and Sfax Local Meteoric Water Lines (Fig. 2), 
152 indicating that the rainfall contributing to the recharge did not undergo any significant

153 evaporation before infiltration.

154 All waters are tagged to various degree with environmental tracers of the post1551950 era (Table 1). In spite of this, all carbon-14 values (range : 2.2 to $68.7 \mathrm{pmC}$ ) are 156 well below the natural modern pre-nuclear value of $100 \mathrm{pmC}$. The lowest value

157 corresponds to the carbo-gaseous waters of Ain Garci $\left(\left[\mathrm{HCO}_{3}\right]=19.8 \mathrm{mmol} / \mathrm{l}\right)$, clearly 158 showing the influence of the ${ }^{14} \mathrm{C}$ dilution by dead carbon on the ${ }^{14} \mathrm{C}$ result. $\delta^{13} \mathrm{C}$ TDIC 159 data were used to correct measured ${ }^{14} \mathrm{C}$ activities for dead carbon dilution due to 160 bicarbonate formation during the reaction between carbonic acid originating from soil $161 \mathrm{CO}_{2}$ and carbonate minerals (Clark and Fritz, 1997; Han and Plummer, 2016). For 162 this correction, the initial $\delta^{13} \mathrm{C}$ value in groundwater recharge prior to leaving the 163 water-soil gas interaction zone is set to $-12 \%$ (Clark and Fritz, 1997; Fourré et al., 164 2011) and the $\delta^{13} \mathrm{C}$ of the marine carbonate limestone formations (see Appendix $A$ ) is 165 assumed to be $0 \%$ (Clark and Fritz, 1997).

166 Neon excess relative to solubility equilibrium at the recharge temperature and 167 elevation ranges from $-0.4 \%$ to $50.1 \%$ (mean value of $21.4 \%$ ), with the exception of 168 Marwa which show a very large excess in 2009 (230\%). This large anomaly, which is 169 confirmed by the analysis of a backup sample, is not seen in $2010(26.6 \%)$. The most 170 probable explanation for the difference between 2009 and 2010 is the sampling 171 location : inside the bottling building in 2009 and at the well head in 2010. The neon 172 data are used to correct all tracer gas concentrations $\left({ }^{3} \mathrm{He},{ }^{4} \mathrm{He}, \mathrm{CFCs}\right.$ and $\left.\mathrm{SF}_{6}\right)$ for 173 excess air (Aeschbach-Hertig et al., 1999) prior to age calculations and tracer 174 comparisons. In addition, all tracer concentrations are normalized to sea-level 175 pressure and a common temperature of $15^{\circ} \mathrm{C}$ to allow the comparison of all sites. 
CFCs and $\mathrm{SF}_{6}$ ages were determined from the direct comparison of the

groundwater tracer concentration with the time-dependent concentration of the tracer in the groundwater recharge.

The ${ }^{3} \mathrm{H} /{ }^{3} \mathrm{He}$ age $\tau$ is defined as $\tau=\lambda^{-1} \operatorname{Ln}\left(1+{ }^{3} \mathrm{He}\right.$ tri $\left./{ }^{3} \mathrm{H}\right)$, where $\lambda$ is the decay constant of tritium and ${ }^{3} \mathrm{H}$ the measured tritium concentration. It is usually expressed in tritium units (TU) : $1 \mathrm{TU}$ corresponds to a ${ }^{3} \mathrm{H} / \mathrm{H}$ ratio of $10^{-18}$. ${ }^{3} \mathrm{He}$ tri is the fraction of the total ${ }^{3} \mathrm{He}$ that is produced by ${ }^{3} \mathrm{H}$ decay, i.e. the difference between the measured concentration ${ }^{3} \mathrm{He}_{\text {meas }}$ and the concentrations of other ${ }^{3} \mathrm{He}$ components: ${ }^{3} \mathrm{He}$ atm of atmospheric origin, and ${ }^{3} \mathrm{He}$ ter, the terrigenic component: ${ }^{3} \mathrm{He}_{\text {tri }}=\left({ }^{3} \mathrm{He}_{\text {meas }}{ }^{3} \mathrm{He}_{\text {atm }}{ }^{-}\right.$ $\left.{ }^{3} \mathrm{He}_{\text {ter }}\right) .{ }^{3} \mathrm{He}_{\mathrm{atm}}$ and ${ }^{3} \mathrm{He}_{\text {ter }}$ are deduced from the measured concentrations of helium and neon. A terrigenic ratio ${ }^{3} \mathrm{He}_{\mathrm{ter}} /{ }^{4} \mathrm{He}$ ter of $2 \times 10^{-8}$ typical isotope ratio for radiogenic helium production in rocks was used, according to the work of Fourré et al. 2011 which shows the absence of mantle helium in the studied area (except for Ain Garci see below). Note that ${ }^{3} \mathrm{He}$ ter is very small, therefore ${ }^{3} \mathrm{He}$ tri is relatively insensitive to the value of this terrigenic ${ }^{3} \mathrm{He} /{ }^{4} \mathrm{He}$ ratio.

Tracer ages are reported in Table 2 and Figure 3. (Fig. 3). SF 6 ages are younger and $\mathrm{F}-11$ ages older than ${ }^{3} \mathrm{H} /{ }^{3} \mathrm{He}, \mathrm{F}-12$ and $\mathrm{F}-113$ ages, possibly due to in-situ terrigenic $\mathrm{SF}_{6}$ production and F-11 breakdown (see section 4 below). For Ain Garci, ${ }^{3} \mathrm{H}-{ }^{3} \mathrm{He}$ dating was problematic due to the presence of mantle ${ }^{3} \mathrm{He}$ $\left({ }^{3} \mathrm{He} /{ }^{4} \mathrm{He}=2.4 \times \mathrm{Ra}-\right.$ see Fourré et al., 2011). ${ }^{3} \mathrm{H} /{ }^{3} \mathrm{He}, \mathrm{F}-12$ and $\mathrm{F}-113$ ages range from 10 to 58 years but tracer ages show substantial discrepancies. Age calculations assume that groundwater moves along independent flowlines analogous to pipes (piston flow). However, tracer-tracer plots (see section 4 below) indicate that the groundwaters are a mixture of modern waters withwith older (tracer-free) waters. Therefore, the piston flow conditions are not valid here and under these conditions it 
201 is not possible to assign ages to tracer concentrations. Therefore tracer ages 202 reported here are not true ages but "apparent" ages (Suckow, 2014). Actual tracer concentrations are modified by this mixing which, in turn, variously affects tracer ages, thus explaining the substantial discrepancies among tracers.

\section{Discussion}

Figure $4 \mathrm{a}$ displays the mean annual atmospheric concentrations of $\mathrm{CFCs}_{\mathrm{S}} \mathrm{SF}_{6}$ and ${ }^{14} \mathrm{C}$ as a function of time for the northern hemisphere. For tritium, the past history 210 of its concentration in precipitation in Tunisia was constructed using all historical 211 measurements from Central Mediterranean stations in the IAEA Global Network of 212 Isotopes in Precipitation database (at https://nucleus.iaea.org/wiser/gnip.php), 213 including the times-series of tritium in rainwater for Tunis and Sfax (Fig. 4b). Tunis 214 data agree with Central Mediterranean IAEA stations between 1970-1980 and then 215 seems to be overestimated, possibly due to data quality problems (some 216 contamination or analytical problems may be suspected). Sfax is on the lower side of 217 the IAEA central Mediterranean dataset, which is consistent with its southern 218 location. C-14 and tritium data are averaged using a polynomial function. The curves 219 in Figure 4a and 4b provide the basis for model calculations of the theoretical 220 relationships between the concentrations of the different transient tracers in 221 groundwater under various mixing assumptions.

222 Figure 5 compares the groundwater concentrations of F-11, F-12, F-113 and SF 6 223 for all groundwaters with the piston flow (PF) model, i.e. along tubular flow lines from 224 recharge to discharge with no mixing of the flow lines. Each curve (in black) 225 represents the relationship between a given tracer pair for recharge dates going back 
226 in time from the sampling date (2010) to the pre-1950s years corresponding to waters beyond the time-scale of the transient tracers. As a variante to this simple 228 piston flow model, we have also calculated the tracer-tracer relationships (blue 229 curves) for the PF model with a typical dispersion coefficient of $10^{-4} \mathrm{~cm}^{2} / \mathrm{sec}$ along 230 the direction of the flow (PF+DIS). Figure 5 shows that at all sites the groundwater 231 concentrations disagree with both models and are better explained (dotted line) by a 232 simple binary mixing (BM) between "modern" waters (upper right corner) and "old" 233 tracer free waters (lower left corner). The PF and BM curves define the region that 234 should contain all tracer data if no additional process other than mixing affects the 235 tracer concentration (permitted region). In Figure $5 \mathrm{~b}$ and $5 \mathrm{c}$, most $\mathrm{SF}_{6}$ and $\mathrm{F}-11$ 236 concentrations are somewhat outside the permitted region. As already noted above 237 when comparing the tracer ages (section 3), this indicates a small but significant 238 additional $\mathrm{SF}_{6}$ component likely due to in-situ production (Harnisch and Eisenhauer, 239 1998; Busenberg anf Plummer, 2000; Deeds et al., 2008; Lapworth et al., 2015) as 240 well as some F-11 in-situ degradation (Oster et al., 1996; Shapiro et al., 1997; 241 Höhener et al., 2003).

242 This mixing trend defined by CFC tracer plots is also apparent on the tritium-F12 243 and tritium-radiocarbon diagrams (Fig. 6a and 6b). This latter diagram also suggests 244 that, for the various studied sites, the old water ${ }^{14} \mathrm{C}$ endmember is in the range $5-$ $24550 \mathrm{pmC}$, corresponding to radiocarbon ages between one and four radiocarbon half246 lifes (approximately 5000 to 20000 years). Radiogenic ${ }^{4} \mathrm{He}$ was plotted against these 247 radiocarbon ages (not shown) since one would expect radiogenic ${ }^{4} \mathrm{He}$ coming with 248 the old water. However, as already noticed in the above Results section, for all the 249 sites ${ }^{3} \mathrm{He}_{\text {ter }}$ and ${ }^{4} \mathrm{He}$ ter are very small and do not provide any clear evidence of a 
250 correlation with ${ }^{14} \mathrm{C}$ ages. This is probably because the old waters are too shallow to 251 pick-up significant crustal helium.

252 The fraction of old water present at each site, estimated from the F113 - F12 or 253 tritium - F12 diagrams, is shown in Fig. 7.

254 Qualitatively, one may say that this factor of dilution by the old waters is an 255 indication of size of the reservoir, and therefore of the sustainability of groundwater 256 resource. More quantitatively, the evolution of the tracer concentration $C_{n}$ at year $n$ 257 (for a well-mixed deep reservoir) can be deduced from the tracer concentration $\mathrm{C}_{\mathrm{n}-1}$ at year $n-1$ by writing the following tracer balance equation:

$$
A H_{n} C_{n}=A H_{n-1} C_{n-1}+\left[A r\left(C_{\text {surf }}\right)_{n}-A w C_{n-1}\right] \Delta t
$$

260 where $\Delta t$ equals 1 year, $r$ (in m/year) is the water recharge rate and $w$ (in $\mathrm{m} /$ year) is 261 the withdrawal rate (both natural and anthropic). A (in $\mathrm{m}^{2}$ ) is the surface area of the 262 recharge zone, $\left(\mathrm{AH}_{\mathrm{n}}\right)$ and $\left(\mathrm{AH}_{\mathrm{n}-1}\right)$ are the volume of groundwater at year $\mathrm{n}$ and $\mathrm{n}-1$ (in 263 $\left.\mathrm{m}^{3}\right)$ and $\left(\mathrm{C}_{\text {surf }}\right)_{n}$ is the tracer concentration in the recharge water of the year $n$. In a similar way, the time-evolution of the volume of groundwater obeys the 265 following equation:

$$
A H_{n}=A H_{n-1}+(A r-A w) \Delta t
$$

If one introduces the renewal time $\tau_{n}$ of the groundwater defined by $\tau_{n}=H_{n} / r$, equations (1) and (2) can be rewritten as follows :

$$
\mathrm{C}_{\mathrm{n}} \tau_{\mathrm{n}}=\mathrm{C}_{\mathrm{n}-1} \tau_{\mathrm{n}-1}+\Delta \mathrm{t}\left[\left(\mathrm{C}_{\text {surf }}\right)_{\mathrm{n}}-\mathrm{C}_{\mathrm{n}-1} \mathrm{w} / \mathrm{r}\right]
$$

$$
\tau_{n}=\tau_{n-1}+\Delta t(1-w / r)
$$

271 Note that for tritium, a radioactive decay is applied to the concentrations every year 272 (not shown in the above equations). 
The concentration $\mathrm{C}_{2010}$ of each tracer at the year of sampling (2010) is

274 determined by solving equations (1') and (2') as a function of the initial renewal time

$275 \tau_{\text {init }}$ of the undisturbed reservoir (before the commissioning of the bottling plant) for

276 various $w / r$. The value of $w / r$, which is not known precisely, is assumed equal to 1 in

277 natural conditions. For all the sites where groundwater is pumped from a well, different values of $w / r$ between 1 and 10 are tested. Since $C_{2010}$ must be equal to the measured concentration, a value of $\tau_{\text {init }}$ can be determined for each tracer.

280 Calculations start in 1950 for CFC's with an initial concentration set to zero. For 281 tritium, an additional spin-up phase going from 1900 to 1950 is necessary to allow for 282 the establishment of the natural concentration in the groundwater reservoir. Table 3 displays the value of the renewal time at each site calculated for each tracer for $w / r=1$ and $w / r=10$. One can see that the impact of the value chosen for $w / r$ remains limited.

This unexpected result is due to the fact that tracer infiltration started in the 1950's, that is well before the commissioning of most of the sites (see Table 1); as a consequence, because of the small withdrawal time compared to the tracer infiltration history, the influence of the withdrawal rate has not enough time to really make a strong difference. Tritium-based renewal times are systematically higher than those of F-12 and F-113. For the majority of the studied sites, renewal times are in the range 50-150 years and, as expected, increase to several centuries (and even millenia) for the sites that show the highest dilution by old waters (Jannet, Hayet, Sabrine, Marwa).

294 The discrepancy between tritium-based and F-12 / F-133-based renewal times 295 indicates that the well-mixed reservoir hypothesis is clearly oversimplified, thus 296 explaining why the renewal time is affected by the temporal shape of the tracer input 297 function. In actuality, the deep reservoirs are most likely characterized by vertical 
298 gradients in tracer concentration. Therefore, analysing tracer concentrations at

299 various depth as well as monitoring tracer concentrations in the mineral waters as a

300 function of time would be very helpful to get a better view of the actual characteristics 301 of groundwater reservoir at each site.

\section{Conclusion}

We have analysed anthropogenic tracers (tritium/helium-3, SF $6, \mathrm{CFCs}$ and radiocarbon) in eleven mineral waters of northern and central Tunisia.

The analysis of the tracer results show that $\mathrm{SF}_{6}$ and $\mathrm{F}-11$ are not entirely reliable due to an additional $\mathrm{SF}_{6}$ component likely originating from in-situ production and a slight but significant F-11 loss attributed to in-situ degradation. All carbon-14 values are well below the natural modern value clearly showing the influence of the ${ }^{14} \mathrm{C}$

311 dilution by dead Dissolved Inorganic Carbon. Therefore, the tracer analysis focussed 312 mainly on tritium, F-12 and F-113.

313 Tracer-tracer plots indicate that the analysed groundwaters are a mixture of 314 "modern" rainwater with older waters of pre-1950s ages, which constitute the main 315 groundwater reservoir. ${ }^{14} \mathrm{C}$ data suggest that the age of these old waters is of the 316 order of radiocarbon half-life or more.

317 The degree of dilution by these old waters is a qualitative indication of size of the 318 reservoir, and therefore of the sustainability of groundwater resource. More 319 quantitatively, the renewal time of each mineral groundwater was estimated using a well-mixed reservoir hypothesis. Most of the studied sites have groundwater renewal 321 times in range from 50-150 years. For the sites where tracer concentrations are the 322 most diluted by old waters, this value increase to several centuries. However one 
observes some serious discrepancies between tritium based and F-12 / F-133 based results, clearly showing that the well-mixed reservoir hypothesis is oversimplified and calling for additional tracer data and a better resolution of well screens to define the vertical gradients in tracer concentration in the various reservoirs.

\section{Acknowledments}

The authors gratefully acknowledge the helpful contribution of the Office du Thermalisme (Tunis). We also thank the director and technical staff of the mineral water bottling plants for their kindness and assistance during sampling.

\section{Appendix A. Geological setting}

The Tunisian mineral waters are found in various geological domains, trapped in the Jurassic, Upper Cretaceous and Eocene limestone reservoirs as well as the MioPliocene detrital reservoirs.

The Marwa mineral waters are captured by an inclined borehole, upstream of Ain el Hammam natural spring. The latter was captured by the Romans via galleries. The Upper Cretaceous fractured and karstified carbonate aquifer forms a large NE-SW synclinal structure affected by faults in the same direction. The centre of the structure is occupied by Paleocene marls providing partial protection of the aquifer against pollution. The aquifer is supplied by infiltration of precipitation waters through widespread carbonates outcropping and forming the Anntra and El Hara massifs.

Crystalline and Aqualine mineral waters are captured in the Jurassic limestones by two deep drillings of 187 and $96 \mathrm{~m}$ respectively, both located to the NW side of the Zaghouan massif. The waters are supplied by infiltration of precipitation in the 
Zaghouan massif affected by numerous faults: the Zaghouan fault on the SE side and by smaller faults on the NW side (Turki, 1985). The underground flows of Jurassic aquifers waters are oriented towards the NW (mineral water catchment area) and the SE of the Zaghouan massif (Zeriba thermal springs).

The Ain Garci mineral waters are captured by a gallery dug in the Eocene

354 limestones. They are probably mixed with the ascending waters of the upper 355 Cretaceous aquifers (Campanian and Cenomanian-Turonian limestones). The physical-chemical characteristics of the mineral waters suggest a deep supply in relation to volcanic rocks (basalt alkaline) associated with the Cenomanian-Turonian carbonates recorded in Jebel Fadhloun and jebel Abid (Raaf and Althuis, 1952; Laaridhi-Ouazaa, 1994). Ain Garci mineral waters show the highest radioactivity, 360 confirming the influence of volcanic rocks (Ben Belgacem, 2011).

361 The mineral water Safia (Ain Mizeb) is captured by a recent gallery in continuity 362 with a Roman gallery and also by drillings (Ain Ksiba). Ain Mizeb is located about 50 $363 \mathrm{~km}$ south of El Kef and $800 \mathrm{~m}$ above sea level. The aquifer is housed in the Eocene 364 limestones of Sra Ouertène (Jellouli). It is a vast limestone plateau resting on the 365 phosphatic layers and covered in places by marls and lumachelles. This plateau is 366 affected by numerous faults and the source (Ain Mizeb) is associated with a fault 367 bringing the Eocene limestone sediments into contact with the marls. The drilling 368 (SO12) capturing Ain Ksiba is located on the edge of the collapsed part of the massif 369 of Sra Ouertene.

370 The mineral water Dima is recovered by a drilling upstream of the Ain M'rada at 371 the level of the wadi Lassoued syncline. This structure is formed by the Eocene 372 limestones and the central part is occupied by the Upper Eocene-Oligocene 373 sediments. It is affected by a series of oblique faults, the most important of which is 
374 that of Ain Sassi. This structure constitutes an important hydraulic unit from which

375 emerges several sources: Ain Sassi, Ain Badi and Ain M'rada along the faults. The

376 Eocene limestones constitute the Dima mineral water aquifer. The direction flow of

377 groundwater is SW-NE, so water capture is located in the upstream part of the 378 aquifer.

379 Mineral waters of Fourat, Janet, Sabrine and Hayet are captured by drillings in the 380 Miocene detrital Formation: the water table of Janet aquifer is tapped by a $360 \mathrm{~m}$ 381 deep drilling intersecting the Mio-Pliocene detrital Formation near Haffouz (Kairouan) 382 which is in direct contact with Eocene limestone formations.

383 The Fourat mineral water comes from a source located at Ksar Lemsa in the 384 delegation of Oueslatia. The mineral water of Fourat is captured by a deep drilling 385 crossing the Mio-Pliocene formations which are in direct contact with the Eocene 386 limestone.

387 Sabrine waters are captured by a $154 \mathrm{~m}$ deep drilling in the southern part of the 388 Chougafia aquifer. It is trapped in a synclinal basin, the core of which is formed by 389 the Mio-Pliocene siliceous sands and is fed by the reliefs surrounding the structure. 390 The water flow of this aquifer is directed SW-NE (Farid et al., 2015) and the drilling, 391 collecting the mineral water is located in the upstream part of the aquifer.

392 Hayet mineral waters are captured by a $226 \mathrm{~m}$ deep drilling located at Baten El 393 Ghazel in the delegation of Jelma, $45 \mathrm{~km}$ away from Sidi Bouzid. The aquifer is 394 housed in the Miocene sandstone and sealed by marls. Water supply through 395 infiltration occurs throughout sandstones outcropping on the flanks of jebels Labeidh 396 and M'Rihla.

\section{References :}


400 Aeschbach-Hertig, W., Peeters, F., Beyerle, U., Kipfer, R., 1999. Interpretation of 401 dissolved atmospheric noble gases in natural waters. Water Resour. Res., 35, 402 2779-2792.

403

404

405

406

407

408

409

410

411

412

413

414

415

416

417

418

420

Ambach W, Dansgaard W, Eisner H, Mollner J., 1968. The altitude effect on the isotopic composition of precipitation and glacier ice in the Alps: Tellus 20, 595600.

Ayraud, V., Aquilina, L., Labasque, T., Pauwels, H., Molenat, J., Pierson-Wickmann, A.C., Durand, V., Bour, O., Tarits, C., Le Corre, P., Fourre, E., Mérot, P., Davy, P., 2008. Compartmentalization of physical and chemical properties in hard rock aquifers deduced from chemical and groundwater age analyses. Appl. Geochem. 23, 2686-2707.

Battle-Aguilar, J., Banks, E.W., Batelaan, O., Kipfer, R., Brennwald, M.S., Cook, P.G., 2017. Groundwater residence time and aquifer recharge in multilayered semi-confined and faulted aquifer systems using environmental tracers. J. Hydrol. $546,150-165$

Baudron, P., Barbecot, F., Gillon, M., Arostegui, J.L.G., Travi, Y., Leduc, C., Gomariz Castillo, F., Martinnez-Vicente, D., 2013. Assessing groundwater residence time in a highly anthropized unconfined aquifer using bomb peak ${ }^{14} \mathrm{C}$ and reconstructed irrigation ${ }^{3} \mathrm{H}$. Radiocarbon 55, 993-1006.

Ben Belgacem, S., 2011. Les activités alpha et bêta globales dans l'eau minérale tunisienne. PFE Chimie Industrielle INSA Tunis, 61 pp. 
421 Beyerle, U., Aeschbach-Hertig, W., Hofer, M., Imboden, D.M., Baur, H., Kipfer, R., 422 1999. Infiltration of river water to a shallow aquifer investigated with ${ }^{3} \mathrm{H} /{ }^{3} \mathrm{He}$, noble gases and CFCs. J. Hydrol. 220, 169-185.

Bullister, J.L., 2011. Atmospheric CFC-11, CFC-12, CFC-113, CCl4 and SF6 Histories. http://cdiac.ornl.gov/ftp/oceans/CFC_ATM_Hist/. Carbon Dioxide Information Analysis Center, Oak Ridge National Laboratory, US Department of Energy, Oak Ridge, Tennessee.doi: 10.3334/CDIAC/otg.CFC_Hist.

Busenberg, E. and Plummer, N.L., 2000. Dating Young Groundwater with Sulfur Hexafluoride: Natural and Anthropogenic Sources of Sulfur Hexafluoride, Water Resour. Res. 36 (10), 3011-3030.

Busenberg, E., Plummer, L.N., 1992. Use of chlorofluorocarbons $\left(\mathrm{CCl}_{3} \mathrm{~F}\right.$ and $\left.\mathrm{CCl}_{2} \mathrm{~F}_{2}\right)$ as hydrologic tracers and age dating tools: the alluvium and terrace system of central Oklahoma. Water Resour. Res. 28, 2257-2283.

434 Busenberg, E., Plummer, L.N., 2000. Dating young groundwater with sulfur hexafluoride: natural and anthropogenic sources of sulfur hexafluoride. Water Resour. Res. 36, 3011-3030.

Celle-Jeanton, H., Zouari, K., Travi, Y., Daoud, A., 2001. Isotopic characterisation of the precipitation in Tunisia. Variations of the stable isotope compositions of rainfall events related to the origin of air masses. Compte-rendus de l'Académie des Sciences, série lla, 333, 625-631.

441 Clark, I. and Fritz, P., 1997. Environmental isotopes in hydrogeology. Lewis 442 Publishers, CRC Press, New York, 331pp. 
443 Cook, P.G., Solomon, D.K., 1995. Transport of trace gases to the water table:

444 Implications for groundwater dating with chlorofluorocarbons and krypton-85.

$445 \quad$ Water Resour. Res. 31, 263-270.

446 Corcho Alvarado, J.A., Purtschert, R., Hinsby, K., Troldborg, L., Hofer, M., Kipfer, R., 447 Aeschbach-Hertig, W., Arno-Synal H., $2005 .{ }^{36} \mathrm{Cl}$ in modern groundwater dated by 448 a multi-tracer approach $\left({ }^{3} \mathrm{H} /{ }^{3} \mathrm{He}, \mathrm{SF}_{6}, \mathrm{CFC}-12\right.$ and $\left.{ }^{85} \mathrm{Kr}\right)$ : a case study in 449 quaternary sand aquifers in the Odense Pilot River Basin, Denmark. Appl. $450 \quad$ Geochem. 20, 599-609.

451 Corcho Alvarado, J.A., Purtschert, R., Barbecot, F., Chabault, C., Rueedi, J., 452 Schneider, V., Aeschbach-Hertig, W., Kipfer, R. and Loosli, H. H., 2007. 453 Constraining the age distribution of highly mixed groundwater using ${ }^{39} \mathrm{Ar}$ : A 454 multiple environmental tracer $\left({ }^{3} \mathrm{H} /{ }^{3} \mathrm{He},{ }^{85} \mathrm{Kr},{ }^{39} \mathrm{Ar}\right.$ and $\left.{ }^{14} \mathrm{C}\right)$ study in the 455 semiconfined Fontainebleau Sands Aquifer (France). Water Resour. Res. 43, W03427, doi:10.1029/2006WR005096.

457 Craig, H., 1961. Isotopic variation in meteoric water. Science 133, 1702-1703.

458 Darling, W.G., Gooddy D.C., MacDonald A.M., Morris B.L., 2012. The practicalities of 459 using $\mathrm{CFCs}$ and $\mathrm{SF}_{6}$ for groundwater dating and tracing. Appl. Geochem. 27, $460 \quad 1688-1697$.

461 Deeds, D.A., Vollmer, M.K., Kulongoski, J.T., Miller, B.R., Mühle, J., Harth, C.M., 462 Izbicki, J.A., Hilton, D.R. and Weiss, R.F., 2008. Evidence for Crustal Degassing 463 of $\mathrm{CF}_{4}$ and $\mathrm{SF}_{6}$ in Mojave Desert Groundwaters, Geochim. Cosmochim. Acta 72, 464 999-1013.

465 Delbart, C., Barbecot, F., Valdes, D., Tognelli, A., Fourré, E., Purtschert, R., 466 Couchoux, L., Jean-Baptiste, P., 2014. Investigation of young water inflow in karst 

aquifers using $\mathrm{SF}_{6}-\mathrm{CFC}-{ }^{3} \mathrm{H} / \mathrm{He}-{ }^{85} \mathrm{Kr}-{ }^{39} \mathrm{Ar}$ and stable isotope components. Appl. Geochem. 50, 164-176.

Farid, I., Zouari, K., Rigane, A., Beji, R., 2015. Origin of the groundwater salinity and geochemical processes in detrital and carbonate aquifers: Case of Chougafiya basin (Central Tunisia). J. Hydrol. 530, 508-532.

Fourré E., Di Napoli, R., Aiuppa, A., Parello, F., Gaubi, E., Jean-Baptiste, P., Allard, P., Calabrese, S., Ben Mammou, A., 2011.Regional variations in the chemical and helium-carbon isotope composition of geothermal waters across Tunisia. Chemical Geology 288, 67-85.

Frija, A., Chebil, A., Speelman, S., Faysse, N., 2014. A critical assessment of groundwater governance in Tunisia. Water Policy 16, 358-373.

Gat, J.R. and Carmi, I., 1970. Evolution of the isotopic composition of atmospheric waters in Mediterranean Sea area, J. Geophys. Res. 75, 3039-3048.

480 Gooddy, D.C., Darling, W.G., Abesser, C., Lapworth, D.J., $2006 . \quad$ Using chlorofluorocarbons (CFCs) and sulphur hexafluoride $\left(\mathrm{SF}_{6}\right)$ to characterise groundwater movement and residence time in a lowland Chalk catchment. J. Hydrol. 330, 44-52.

Harnisch, J. and Eisenhauer, A., 1998. Natural $\mathrm{CF}_{4}$ and $\mathrm{SF}_{6}$ on Earth. Geophys. Res. Lett. 25 (13), 2401-2404.

Han, L.F., Plummer, L.N., 2016. A review of single-sample-based models and other approaches for radiocarbon dating of dissolved inorganic carbon in groundwater. Earth Science Reviews 152, 119-142. fate of chlorofluorocarbons in groundwater. Water Resour. Res. 33, 1-33. 
491 Jean-Baptiste, P., Mantisi, F., Dapoigny, A., Stievenard, M., 1992. Design and

492 performance of a mass spectrometric facility for measuring helium isotopes in 493 natural waters and for low-level tritium determination by the ${ }^{3} \mathrm{He}$ ingrowth method. 494 Int. J. Radiat. Appl. Instrum. 43, 881-891.

495 Jean-Baptiste, P., Fourré, E., Dapoigny, A., Baumier, D., Baglan, N., Alanic, G., 496 2010. ${ }^{3} \mathrm{He}$ mass spectrometry for very low-level measurement of organic tritium 497 in environmental samples. J. Environ. Rad., 101, 185-190.

498 Kralik, M., Humer, F., Fank, J., Harum, T., Klammler, G., Gooddy, D., Sültenfuß, J., 499 Gerber, C., Purtschert, R. 2014. Using ${ }^{18} \mathrm{O} /{ }^{2} \mathrm{H},{ }^{3} \mathrm{H} /{ }^{3} \mathrm{He},{ }^{85} \mathrm{Kr}$ and $\mathrm{CFCs}$ to 500 determine mean residence times and water origin in the Grazer and Leibnitzer $501 \quad$ Feld groundwater bodies (Austria). Appl. Geochem. 50, 150-163.

502 Laaridhi-Ouazaa, N., 1994. Etude minéralogique et géochimique des épisodes 503 magmatiques mésozoïques et miocènes de la Tunisie. PhD Thesis, Univ. Tunis II, 504 $457 \mathrm{pp}$.

Labasque, T., Ayraud, V., Aquilina, L., Le Corre, P., 2006. Dosage des composés chlorofluorocarbonés et du tétrachlorure de carbone dans les eaux souterraines. Application à la datation des eaux. Editions Géosciences Coll Cahiers Techniques. ISBN:2-914375-38-7.

Lapworth, D.J., MacDonald, A.M., Krishan, G., Rao, M.S., Gooddy, D.C. and Darling, W.G., 2015. Groundwater recharge and age-depth profiles of intensively exploited groundwater resources in northwest India, Geophys. Res. Lett., 42, 7554-7562, doi:10.100 2/2015GL0657 98.

513 Lucas, L.L., Unterweger, M.P., 2000. Comprehensive review and critical evaluation of 514 the half-life of tritium. J. Res. Natl. Inst. Stand. Technol. 105, 541-549. 
515 Massmann, G., Sültenfuß, J.,Dünnbier, U., Knappe, A., Taute, T., Pekdeger, A.,

516 2008. Investigation of groundwater residence times during bank filtration in Berlin: 517 a multi-tracer approach. Hydrol. Process. 22, 788-801.

518 Mayer, A., Sültenfuß, J., Travi, Y., Rebeix, R., Purtschert, R., Claude, C., Le Gal La

519 Salle, C., Miche, H., Conchetto, E., 2014. A multi-tracer study of groundwater 520 origin and transit-time in the aquifers of the Venice region (Italy). Appl. Geochem. $521 \quad 50,177-198$.

522 Nydal, R., and K. Lövseth. 1996. Carbon-14 Measurements in Atmospheric $\mathrm{CO}_{2}$ from 523

526 Oster, H., Sonntag, C., Munnich, K.O., 1996. Groundwater age dating with chlorofluoro-carbons. Water Resour. Res. 32 (10), 2989-3001.

528 Plummer, L.N., Busenberg, E., Böhlke, J.K., Nelms, D.L., Michel, R.L., Schlosser, P., 529 2001. Groundwater residence times in Shenandoah National Park, Blue Ridge

530 Mountains, Virginia, USA: a multi-tracer approach. Chemical Geology 179, 93531111.

532 Plummer, L.N. and Glynn, P.D., 2013. Radiocarbon dating in groundwater systems. 533 In: Isotope methods for dating old groundwater, International Atomic Energy 534 Agency, Vienna, STI/PUB/1587, Chapter 4, 33-89.

535 Poreda, R.J., Cerling, T.E. and Solomon, D.K., 1988. Tritium and helium isotopes as 536 hydrologic tracers in a shallow unconfined aquifer. J. Hydrol., 103, 1-9. 
537 Raaf, J.F.M. and Althuis, S.P., 1952. Présence d'ophites spilitiques dans le Crétacé

538 des environs d'Enfidaville. $19^{\text {th }}$ International Geological Congress, Algiers, $2^{\text {d }}$ Ser.

539 Tunisia 6, 127-137.

540 Schlosser, P., Stute, M., Dörr, H., Sonntag, C. and Münnich, K.O., 1988. Tritium/3 $\mathrm{He}$

541 dating of shallow groundwater. Earth Planet. Sci. Lett., 89, 353-362.

542 Shapiro, S.D., Schlosser, P., Smethie, W.M., Stute, M., 1997. The use of H-3 and 543 tritiogenic He-3 to determine CFC degradation and vertical mixing rates in $544 \quad$ Framvaren Fjord, Norway. Marine Chemistry 59 (1-2), 141-157.

545 Siegenthaler, U. and Oeschger, H., 1980. Correlation of ${ }^{18} \mathrm{O}$ in precipitation with 546 temperature and altitude, Nature 285, 314-317.

547 Solomon, D.K. and Sudicky, E.A., 1991. Tritium and helium-3 isotope ratios for direct 548 estimation of spatial variations in groundwater recharge. Water Resour. Res., $549 \quad 27(9), 2309-2319$.

550 Solomon, D.K., Schiff, S.L., Poreda, R.J. and Clarke, W.B., 1993. A validation of the 551

Solomon D.K., Genereux D.P., Plummer L.N., Busenberg E., 2010. Testing mixing ${ }^{3} \mathrm{H} /{ }^{3} \mathrm{He}$ method for determining groundwater recharge. Water Resour. Res., 29(9), $2951-2962$.

Stewart, M.K., 2012. A 40-year record of carbon-14 and tritium in the Christchurch groundwater system, New Zealand: dating of young samples with carbon-14. J. Hydrol. 430, 50-68. 
560 Stute, M., Deák, J., Révész, K., Böhlke, J.K., Deseö, E., Weppernig, R., Schlosser, P., 1997. Tritium $/{ }^{3} \mathrm{He}$ dating of river infiltration: an example from the Danube in the Szigetköz Area, Hungary. Groundwater 35 (5), 905-911.

563 Suckow, A., 2014. The age of groundwater - Definitions, models and why we do not need this term. Appl. Geochem. 50, 222-230.

565 Szabo, Z., Rice, D.E., Plummer, L.N., Busenberg, E., Drenkard, S., Schlosser, P., 566 1996. Age dating of shallow groundwater with chlorofluorocarbons, tritium/helium3, and flow path analysis, southern New Jersey coastal plain. Water Resour. Res. 32 (4), 1023-1038.

569 Thompson, G.M. and Hayes J.M., 1979. Trichloromethane in groundwater: A 570 possible tracer and indicator of groundwater age. Water Resour. Res., 15, 546571554.

572 Turki M.M., 1985. Polycinématique et contrôle sédimentaire associé sur la cicatrice 573 Zaghouan- Nebhana. PhD Thesis, Univ. Tunis. C. ST-INRST Ed., 7, 252 pp. 
Figure captions

578

Fig.1 : Map of Northern and Central Tunisia showing the location of the groundwater sampling sites.

Fig.2 : Comparison of the stable isotopic composition of precipitation with the isotopic composition of the groundwaters. Tunis and Sfax Local Meteoric Water Lines (dotted lines) are from Celle-Jeanton et al. (2001). The Global Meteoric Water Line (GMWL) and Mediterranean Meteoric Water Line (MMWL) are from Craig (1961) and Gat \& Carmi (1970), respectively.

Fig.3 : Tracer ages comparison : ${ }^{3} \mathrm{H}-{ }^{3} \mathrm{He}$ (light blue), F-11 (red), F-12 (yellow), F-113 (green), $\mathrm{SF}_{6}$ (dark blue)

Fig.4 : Atmospheric concentration of the transient tracers for the northern hemisphere

592 as a function of time. CFC and $\mathrm{SF}_{6}$ curves (a) are from Bullister (2011) and ${ }^{14} \mathrm{C}$ data 593 are from Nydal \& Lövseth (1996). Tritium content of rainwater in Tunisia (b) was constructed using all historical measurements from Central Mediterranean stations in 595 the IAEA Global Network of Isotopes in Precipitation database (at 596 https://nucleus.iaea.org/wiser/gnip.php), including the times-series of tritium in 597 rainwater for Tunis and Sfax.

599 Fig.5 : CFC and $\mathrm{SF}_{6}$ tracer plots showing F-113 versus F-12 (a), SF 6 versus F-12 (b) 600 and F-11 versus F-12 (c). The black and blue curves correspond to the PF model 601 and the PF model + dispersion respectively (see text). Numbers are travel times (in 
602 year) in the PF model. The dotted line represents the mixing between a recharge 603 water of the year 2010 (upper right corner) and an old water endmember with zero 604 tracer concentration (lower left corner).

605

606 Fig.6 : (a) ${ }^{3} \mathrm{H}$ versus F-12. The black and blue curves correspond to the PF model 607 and the PF model + dispersion respectively (see text). Tritium values prior to 2010 608 are decay-corrected using a tritium half-life of $4500 \mathrm{~d}$ (Lucas and Unterweger, 2000). 609 Dotted curve represent mixing between old waters and a recharge water of the year 6102010 . (b) ${ }^{3} \mathrm{H}$ versus ${ }^{14} \mathrm{C}$ (corrected for carbonate dissolution). NB: the initial ${ }^{14} \mathrm{C}$ value

611 of recharge waters, as given by the ${ }^{14} \mathrm{C}$ input function (Fig. 4a), can be modified by

612 interaction of infiltrating water with soil $\mathrm{CO}_{2}$ from plant root respiration and microbial 613 degradation of soil organic matter. In semi-arid to arid environments however, those 614 biological interactions are minimal (Plummer and Glynn, 2013) so this effect is 615 neglected here.

616

617 Fig.7 : Comparison of the fraction of old water present at each site, estimated from 618 the F113 - F12 and tritium - F12 diagrams.

619 


\section{Table captions}

622

623 Table 1 : Summary of the main relevant parameters for the sampled sites

624

625 Table 2: Tracer results. CFCs and $\mathrm{SF}_{6}$ tracer concentrations have been corrected 626 from excess air as defined by neon data and normalized to sea-level pressure and a 627 common temperature of $15^{\circ} \mathrm{C}$ to allow the comparison of all sites (note that the 628 uncertainty on $\mathrm{CFC}_{\text {and }} \mathrm{SF}_{6}$ ages do not take into account the uncertainty on the air 629 excess correction, mostly because of the lack of knowledge of the exact recharge 630 altitude).

631

632 Table 3 : Estimated groundwater renewal time for the various sites based on tritium, 633 F-12 and F-113 data, assuming a well-mixed reservoir (see text). 


\begin{tabular}{|c|c|c|c|c|c|c|c|c|c|c|c|c|c|}
\hline Site & Geographic & Catchment & Well & Year of & Altitude of & \multicolumn{2}{|c|}{ Average temperature $\left({ }^{\circ} \mathrm{C}\right.$} & \multicolumn{3}{|c|}{ Average precipitation (mm) } & Recharge temperature $\left({ }^{\circ} \mathrm{C}\right)$ & $\mathrm{pH}$ & $\mathrm{HCOB}$ \\
\hline & zone & type & depth (m) & commissioning & the site $(\mathrm{m})$ & January & July & January & July & Annual & (precipitation weighed) & & $(\mathrm{mmol} / \mathrm{l})$ \\
\hline Marwa & Bizerte & well & 72 & 1993 & 300 & 11,3 & 25,2 & 77 & 3 & 558 & 13,1 & 7,2 & 4,17 \\
\hline Safia (Ain Mizeb) & 曰 Kef & surface & 0 & 1968 & 880 & 7,1 & 26,5 & 65 & 9 & 509 & 12,9 & 7,3 & 3,87 \\
\hline Safia (Ain Ksiba) & 巨Kef & well & 62 & 1992 & 900 & 7,1 & 26,5 & 65 & 9 & 509 & 12,7 & 7,0 & 3,71 \\
\hline Dima & E Kef & well & $\sim 50$ & 2009 & 750 & 7,1 & 26,5 & 65 & 9 & 509 & 13,7 & 7,5 & 4,04 \\
\hline Cristaline & Zaghouan & well & 187 & 2003 & 200 & 9,6 & 27,0 & 68 & 5 & 496 & 15,2 & 7,4 & 3,79 \\
\hline Aqualine & Zaghouan & well & 96 & 2006 & 200 & 9,6 & 27,0 & 68 & 5 & 496 & 15,2 & 7,6 & 4,40 \\
\hline Ain Garci & Zaghouan & surface & 0 & 1900 & 110 & 9,6 & 27,0 & 68 & 5 & 496 & 15,2 & 6,6 & 19,84 \\
\hline Sabrine & Kairouan & well & 154 & 1991 & 106 & 11,7 & 29,1 & 23 & 5 & 306 & 17,6 & 7,5 & 3,80 \\
\hline Fourat & Kairouan & well & $\sim 150$ & 2003 & 400 & 11,7 & 29,1 & 23 & 5 & 306 & 16,1 & 7,2 & 4,80 \\
\hline Hayet & Kairouan & well & 226 & 1996 & 420 & 11,7 & 29,1 & 23 & 5 & 306 & 16,0 & 7,5 & 2,15 \\
\hline \begin{tabular}{|l|} 
Jannet \\
\end{tabular} & Kairouan & well & 360 & 2002 & 400 & 11,7 & 29,1 & 23 & 5 & 306 & 16,1 & 7,6 & 3,75 \\
\hline
\end{tabular}

Table 1 


\begin{tabular}{|c|c|c|c|c|c|c|c|c|c|c|c|c|c|c|c|c|c|c|c|c|c|c|c|c|c|c|c|c|c|c|c|c|c|c|c|}
\hline \multirow{3}{*}{\begin{tabular}{|l} 
Site \\
\\
Marwa (2009) \\
\end{tabular}} & \multirow{2}{*}{\multicolumn{2}{|c|}{$\begin{array}{l}\text { Tritium } \\
(\mathrm{TU}) \\
\end{array}$}} & \multirow{3}{*}{\begin{tabular}{|c|} 
Neon excess \\
$(\%)$ \\
230,1 \\
\end{tabular}} & \multirow{2}{*}{\multicolumn{3}{|c|}{\begin{tabular}{c|}
$3 \mathrm{H}-3 \mathrm{He}$ age \\
(year)
\end{tabular}}} & \multirow{2}{*}{\multicolumn{3}{|c|}{$\begin{array}{l}\mathrm{F}-11 \\
(\mathrm{pmol} / \mathrm{L})\end{array}$}} & \multirow{2}{*}{\multicolumn{3}{|c|}{$\begin{array}{c}\mathrm{F}-12 \\
(\mathrm{pmol} / \mathrm{L})\end{array}$}} & \multirow{2}{*}{\multicolumn{3}{|c|}{$\begin{array}{c}\mathrm{F}-113 \\
(\mathrm{pmol} / \mathrm{L})\end{array}$}} & \multirow{2}{*}{\multicolumn{3}{|c|}{$\begin{array}{c}\text { SF6 } \\
(\mathrm{pmol} / \mathrm{L})\end{array}$}} & \multirow{2}{*}{\multicolumn{2}{|c|}{$\frac{\text { F-11 age }}{\text { (year) }}$}} & \multirow{2}{*}{\multicolumn{3}{|c|}{\begin{tabular}{|c} 
F-12 age \\
(year) \\
\end{tabular}}} & \multirow{2}{*}{\multicolumn{3}{|c|}{$\frac{F-113 \text { age }}{\text { (year) }}$}} & \multirow{2}{*}{\multicolumn{2}{|c|}{$\begin{array}{c}\text { SF6 age } \\
\text { (year) }\end{array}$}} & \multirow[t]{3}{*}{$2-\mathrm{H}$} & \multirow[t]{3}{*}{ 18-O } & \multirow{2}{*}{\multicolumn{3}{|c|}{$\frac{14-\mathrm{C}}{(\mathrm{pmC})}$}} & \multirow{3}{*}{\begin{tabular}{|c|} 
delta 13-C \\
(permil) \\
$-11,14$ \\
\end{tabular}} & \multirow{3}{*}{\begin{tabular}{|c|} 
14-C corrected \\
(pmC) \\
56,30
\end{tabular}} \\
\hline & & & & & & & & & & & & & & & & & & & & & & & & & & & & & & & & & & & \\
\hline & 1,44 & $\pm 0,13$ & & 34,6 & \pm & 1,4 & & & & & & & & & & & & & & & & & & & & & & & & & 52,27 & \pm & 0,21 & & \\
\hline Marwa & 1,35 & $\pm 0,05$ & 26,6 & 23,9 & \pm & 0,6 & 0,69 & \pm & 0,12 & 0,549 & \pm & 0,07 & 0,081 & \pm 0 & 0,01 & 7,99E-04 & \pm & $1,2 \mathrm{E}-04$ & 42 & \pm 2 & 40 & & 3 & 32 & \pm 2 & & 20 & \pm 2 & $-35,7$ & $|-6,45|$ & & & & & \\
\hline Safia-Ain Mizeb (2009) & 3,29 & \begin{tabular}{|l|l} 
$\pm 0,15$ \\
\end{tabular} & 11,0 & 10,4 & \pm & 2,4 & & & & & & & & & & & & & & & & & & & & & & & $-49,1$ & \begin{tabular}{|l|}
$-7,84$ \\
\end{tabular} & 55,07 & \pm & 0,19 & $-11,82$ & 55,90 \\
\hline Safia-Ain Ksiba & 3,34 & \begin{tabular}{|l|l|} 
\pm & 0,06 \\
\end{tabular} & & 9,98 & \pm & 1,1 & 2,08 & \pm & 0,12 & 320 & 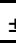 & 0,07 & 208 & \pm 0 & 0,01 & 1,27E-03 & \pm & $1,2 \mathrm{E}-04$ & 34 & \pm 2 & 31 & $1 \pm \pm 2$ & 2 & 25 & \pm 2 & & 13 & \pm 2 & $-49,9$ & \begin{tabular}{|l|}
$-7,66$ \\
\end{tabular} & 58,01 & \pm & 0,22 & $-12,36$ & 58,01 \\
\hline Dima & 3,03 & \begin{tabular}{|l|l|} 
\pm & 0,08 \\
\end{tabular} & 0,1 & 12,9 & \pm & 1,0 & 1,43 & \pm & 0,12 & 1,067 & \pm & 0,07 & 0,176 & \pm 0 & 0,01 & 1,33E-03 & \pm & $1,2 \mathrm{E}-04$ & 37 & \pm 2 & 34 & $4+ \pm 2$ & 2 & 26 & \pm 2 & & 12 & \pm 2 & $-50,5$ & \begin{tabular}{|l|}
$-7,62$ \\
\end{tabular} & 68,72 & \pm & 0,24 & $-12,22$ & 68,72 \\
\hline Cristaline & 3,10 & \begin{tabular}{|l|l|} 
\pm & 0,08 \\
\end{tabular} & 1,5 & 19,8 & \pm & 0,7 & 1,64 & \pm & 0,12 & 1,134 & \pm & 0,07 & 0,165 & \pm 0 & 0,01 & 1,66E-03 & \pm & $1,2 \mathrm{E}-04$ & 36 & \pm 2 & 33 & $3 \pm \pm 2$ & 2 & 24 & \pm 2 & & 8 & \pm 1 & $-36,3$ & $-6,51$ & 67,93 & \pm & 0,24 & $-10,47$ & 77,86 \\
\hline Aqualine & 3,16 & \begin{tabular}{l|l} 
$\pm 0,12$ \\
\end{tabular} & 1 & 19,5 & \pm & 0,6 & 1,64 & \pm & 0,12 & 1,069 & \pm & 0,07 & 0,166 & \pm 0 & 0,01 & 1,73E-03 & \pm & $1,2 \mathrm{E}-04$ & 36 & \pm 2 & 34 & $4+ \pm 2$ & 2 & 26 & \pm 2 & & 7 & \pm 1 & $-36,0$ & \begin{tabular}{|l|}
$-6,52$ \\
\end{tabular} & 66,43 & \pm & 0,21 & $-10,57$ & 75,42 \\
\hline Ain Garci (2009) & 0,49 & \begin{tabular}{|l|l|} 
\pm & 0,04 \\
\end{tabular} & $-0,4$ & & & & & & & & & & & & & & & & & & & & & & & & & & $-31,7$ & $-5,65$ & 2,25 & \pm & 0,09 & $-0,75$ & 36,00 \\
\hline Sabrine & 0,23 & \begin{tabular}{|l|l|} 
$\pm 0,05$ \\
\end{tabular} & 10,9 & 37,1 & \pm & 1,7 & 0,14 & \pm & 0,12 & 0,061 & \pm & 0,07 & 0,034 & \pm 0 & 0,01 & 1,84E-04 & \pm & $1,2 \mathrm{E}-04$ & 51 & \pm 2 & 56 & $6 \pm$ & 3 & 37 & \pm 2 & & 33 & \pm 2 & $-31,6$ & \begin{tabular}{|l|}
$-5,26$ \\
\end{tabular} & 31,30 & \pm & 0,14 & $-8,50$ & 44,19 \\
\hline Fourat & 2,53 & \begin{tabular}{|l|l|} 
$\pm 0,05$ \\
\end{tabular} & 8,2 & 26,8 & \pm & 1,0 & 1,30 & \pm & 0,12 & 0,894 & & 0,07 & 0,136 & \pm 0 & 0,01 & $1,20 \mathrm{E}-03$ & \pm & $1,2 \mathrm{E}-04$ & 38 & \pm 2 & 36 & $6 \pm$ & 2 & 28 & \pm 2 & & 14 & \pm 2 & $-38,8$ & \begin{tabular}{|l|}
$-6,59$ \\
\end{tabular} & 60,66 & \pm & 0,20 & $-11,35$ & 64,13 \\
\hline Hayet & 0,10 & $\pm 0,06$ & 38,8 & 55,7 & \pm & 17,7 & 0,25 & \pm & 0,12 & 0,185 & -1 & 0,07 & 0,031 & \pm 0 & 0,01 & 2,33E-04 & \pm & $1,2 \mathrm{E}-04$ & 48 & \pm 2 & 51 & $1 \pm 3$ & 3 & 43 & \pm 2 & & 31 & \pm 2 & $-32,2$ & \begin{tabular}{|l|}
$-5,10$ \\
\end{tabular} & 34,54 & \pm & 0,16 & $-10,94$ & 37,89 \\
\hline Jannet & 0,12 & \begin{tabular}{|l|l|} 
\pm & 0,07 \\
\end{tabular} & 16,3 & 48,1 & \pm & 16,3 & 0,12 & \pm & 0,12 & 0,045 & \pm & 0,07 & 0,025 & \pm 0 & 0,01 & 3,02E-04 & \pm & $1,2 \mathrm{E}-04$ & 52 & \pm 2 & 58 & 8.5 & 3 & 39 & \pm 2 & & 29 & \pm 2 & \begin{tabular}{|l|}
$-37,2$ \\
\end{tabular} & \begin{tabular}{|l|}
$-6,32$ \\
\end{tabular} & 3,62 & \pm & 0,10 & $-7,49$ & 5,80 \\
\hline
\end{tabular}

Table 2 


\begin{tabular}{|l|c|c|c|c|c|c|}
\hline Site & \multicolumn{2}{|c|}{ Tritium-based renewal time $(\mathrm{yr})$} & \multicolumn{2}{|c|}{ F12-based renewal time $(\mathrm{yr})$} & \multicolumn{2}{|c|}{ F113-based renewal time (yr) } \\
\hline & $\mathrm{w} / \mathrm{r}=1$ & $\mathrm{w} / \mathrm{r}=10$ & $\mathrm{w} / \mathrm{r}=1$ & $\mathrm{w} / \mathrm{r}=10$ & $\mathrm{w} / \mathrm{r}=1$ & $\mathrm{w} / \mathrm{r}=10$ \\
\hline Marwa & 329 & 360 & 131 & 215 & 125 & 215 \\
\hline Safia-Ain Mizeb & 108 & $\mathrm{n} . \mathrm{a}$ & - & - & - & - \\
\hline Safia-Ain Ksiba & 106 & 186 & 41 & 183 & 38 & 183 \\
\hline Dima & 122 & 135 & 57 & 69 & 49 & 61 \\
\hline Cristaline & 118 & 134 & 52 & 89 & 53 & 90 \\
\hline Aqualine & 114 & 129 & 57 & 75 & 53 & 72 \\
\hline Ain Garci & 950 & $\mathrm{n} . \mathrm{a}$ & - & - & - & - \\
\hline Sabrine & 2100 & 2100 & 1320 & 1390 & 320 & 400 \\
\hline Fourat & 155 & 171 & 72 & 102 & 68 & 100 \\
\hline Hayet & 4500 & 4500 & 430 & 470 & 350 & 400 \\
\hline Jannet & 4100 & 4100 & 1800 & 1800 & 440 & 470 \\
\hline
\end{tabular}

Table 3 


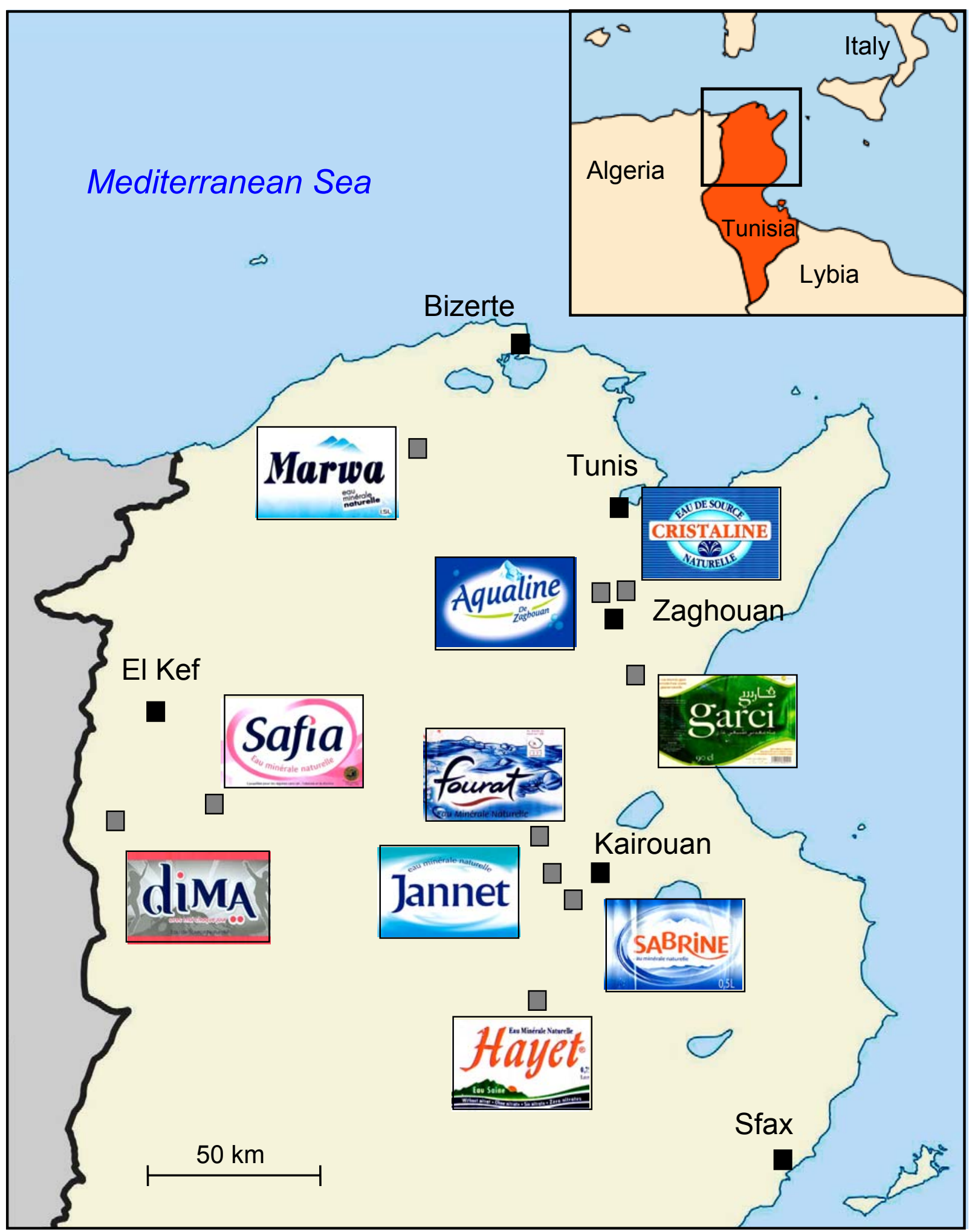

Figure 1 


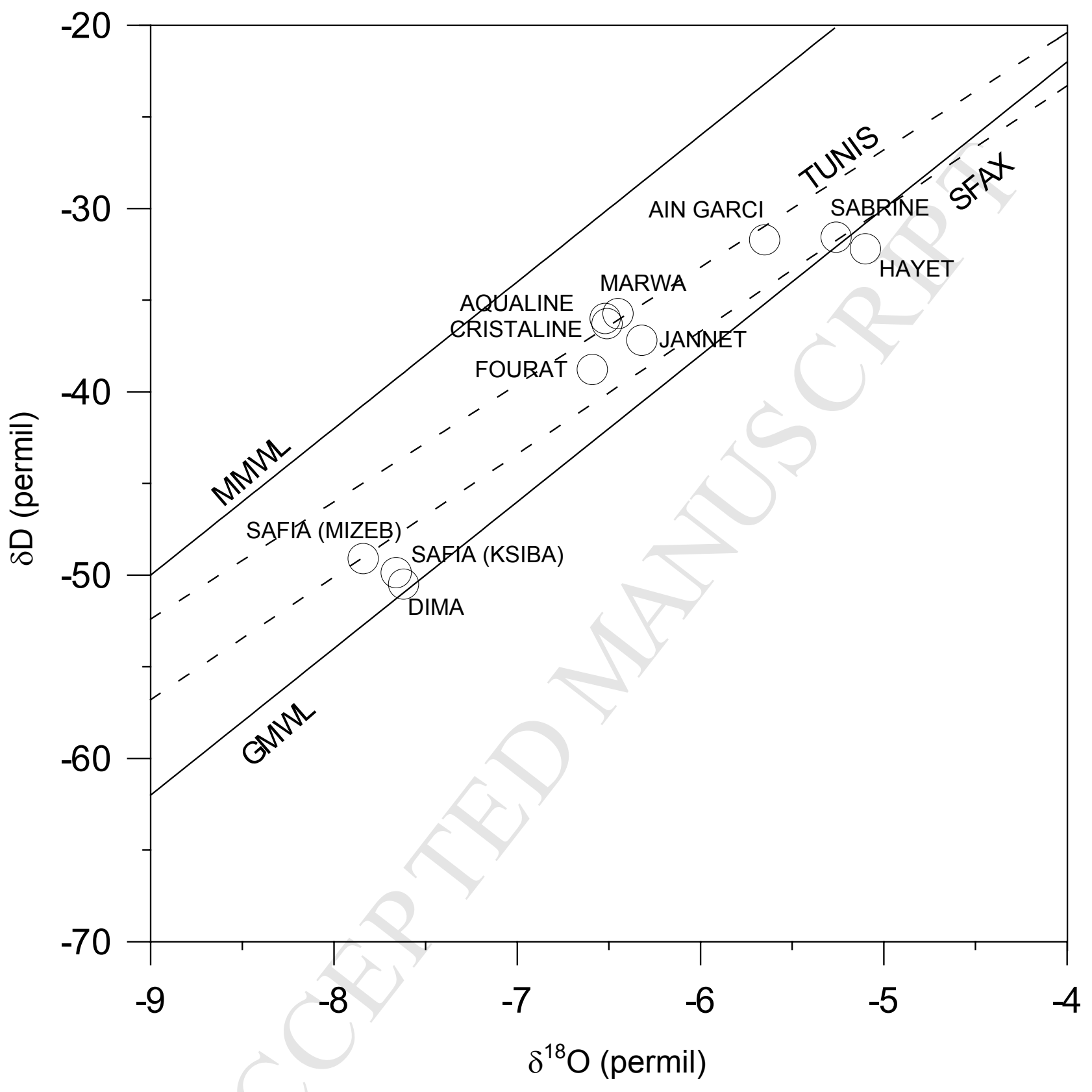

Figure 2 


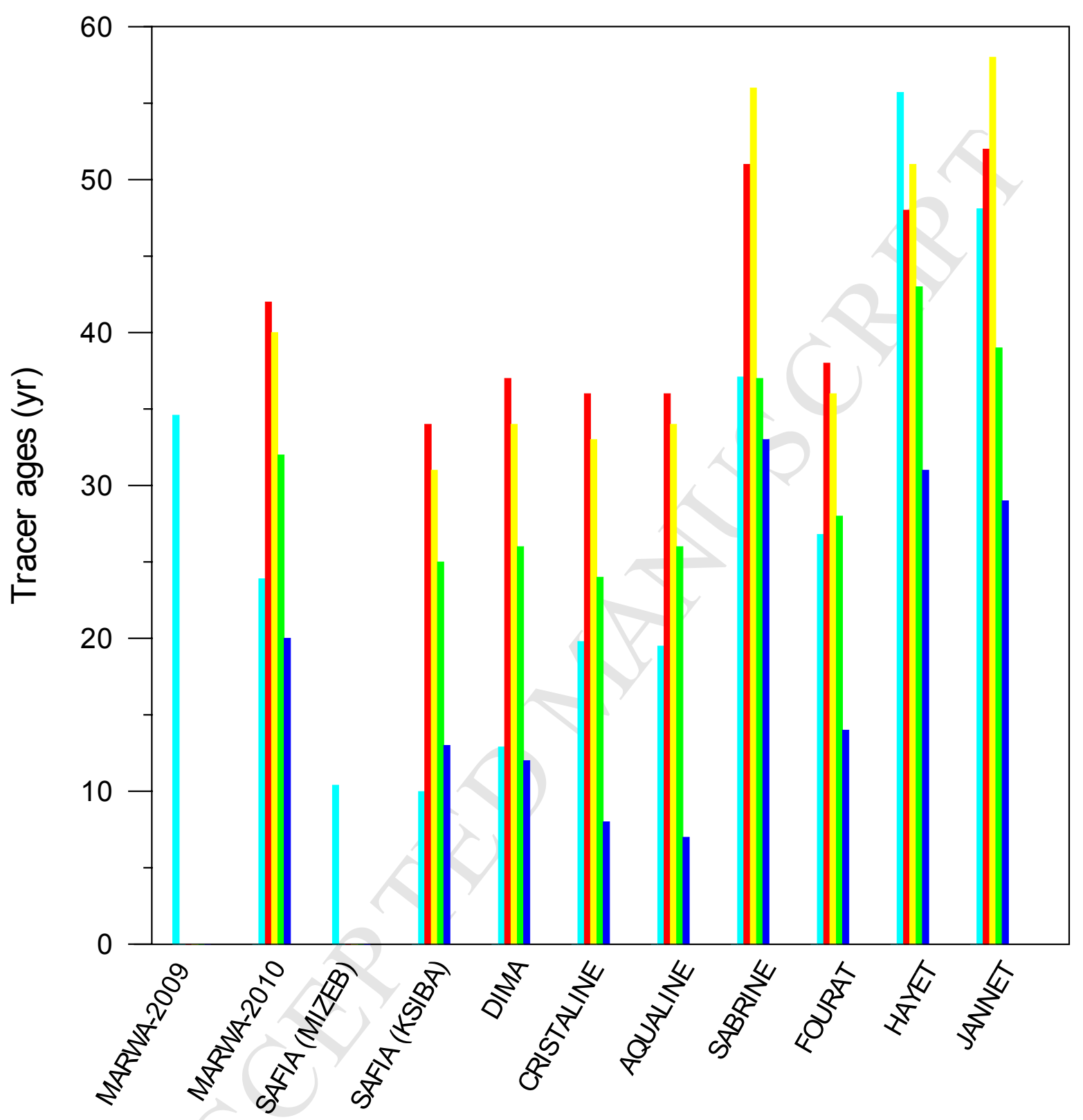

Figure 3 

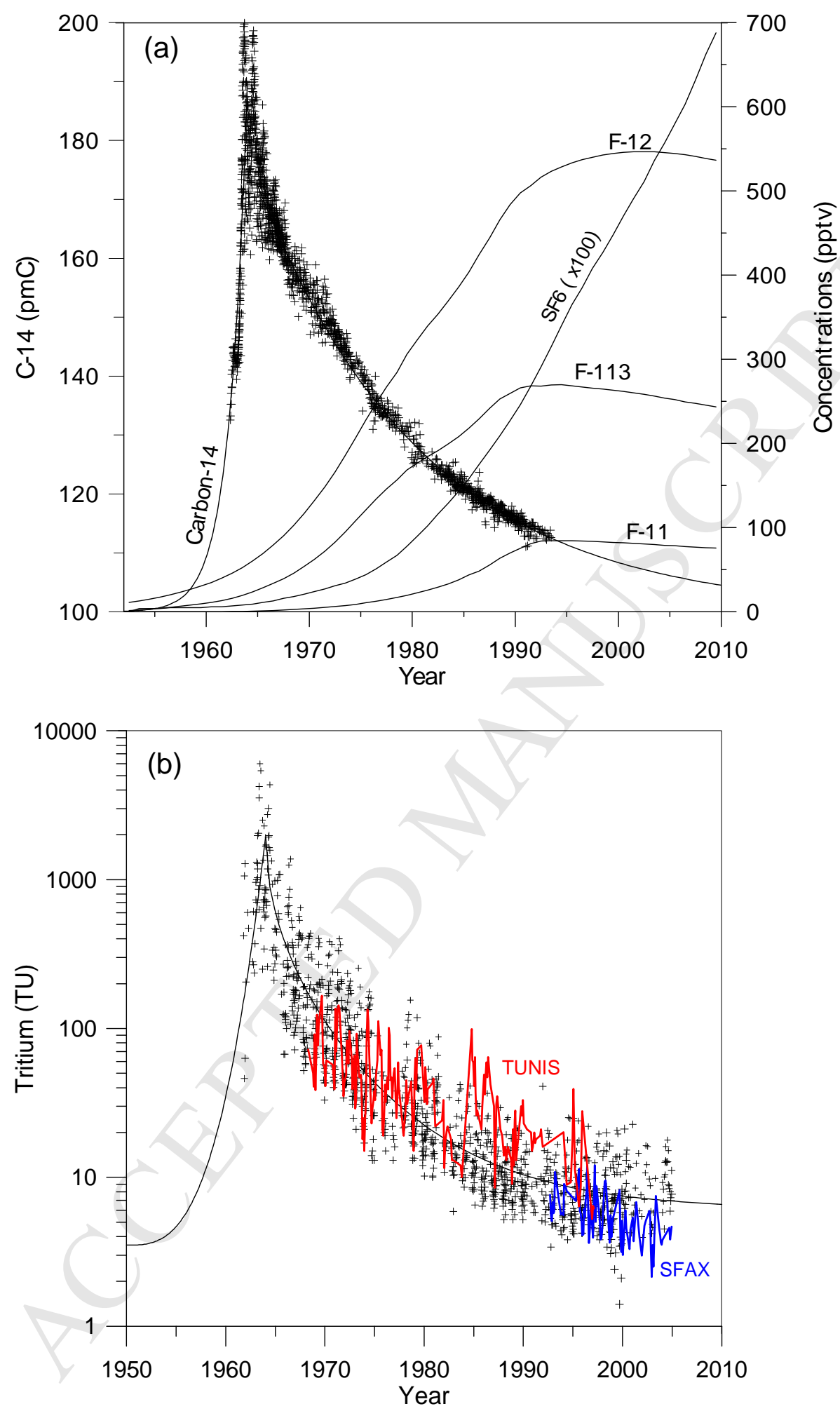

Figure 4 


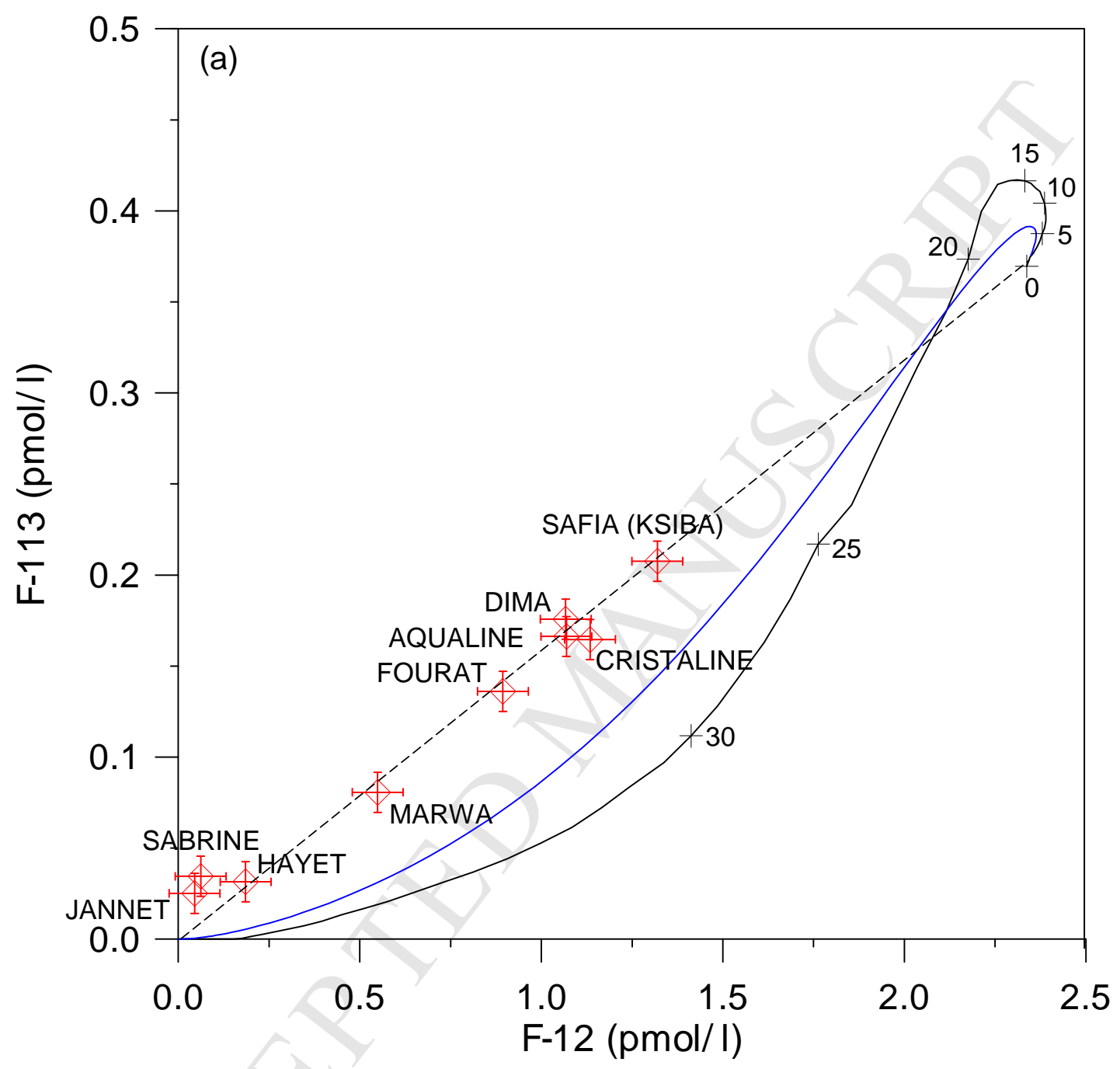

Figure 5a 


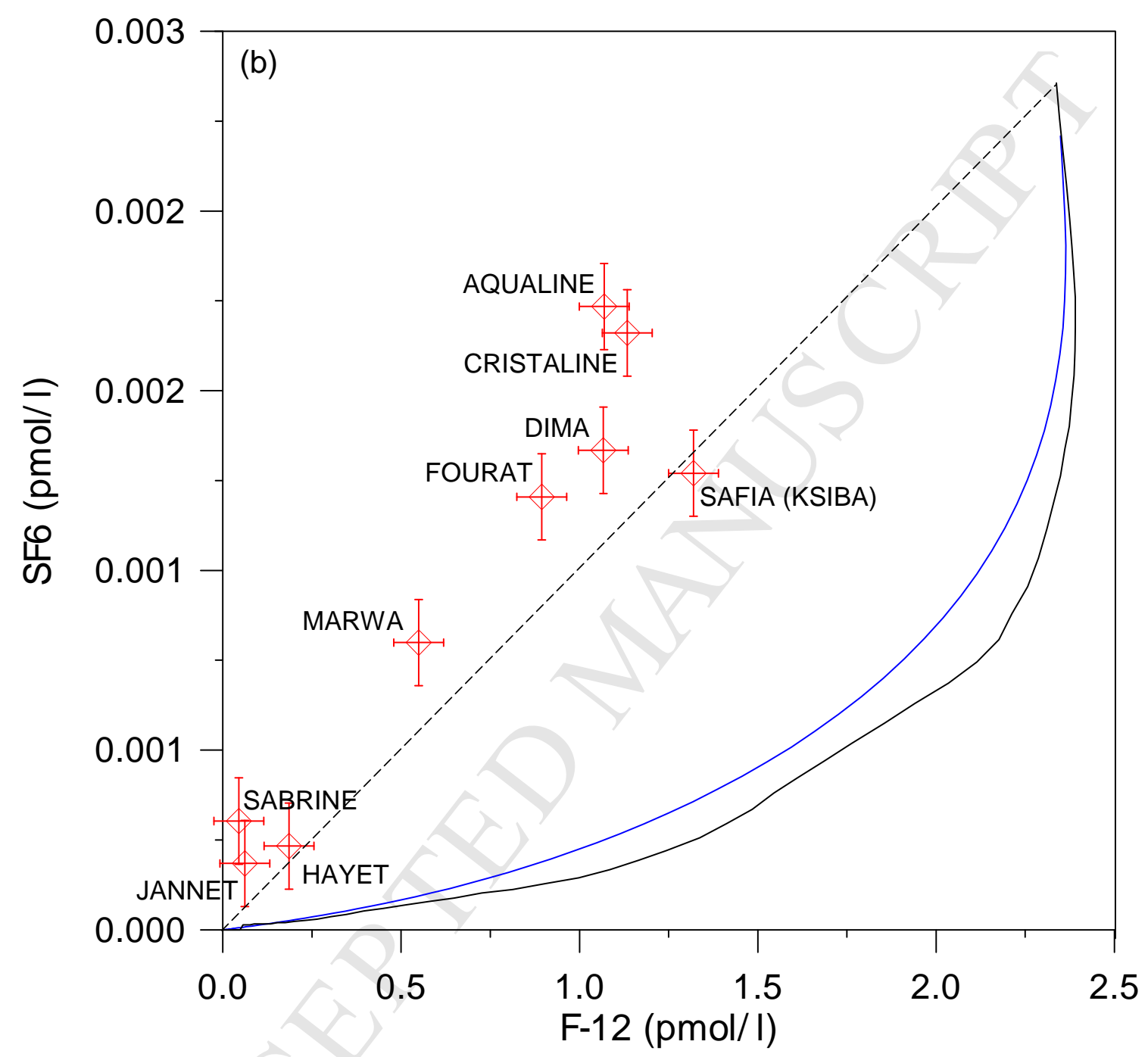

Figure 5b 


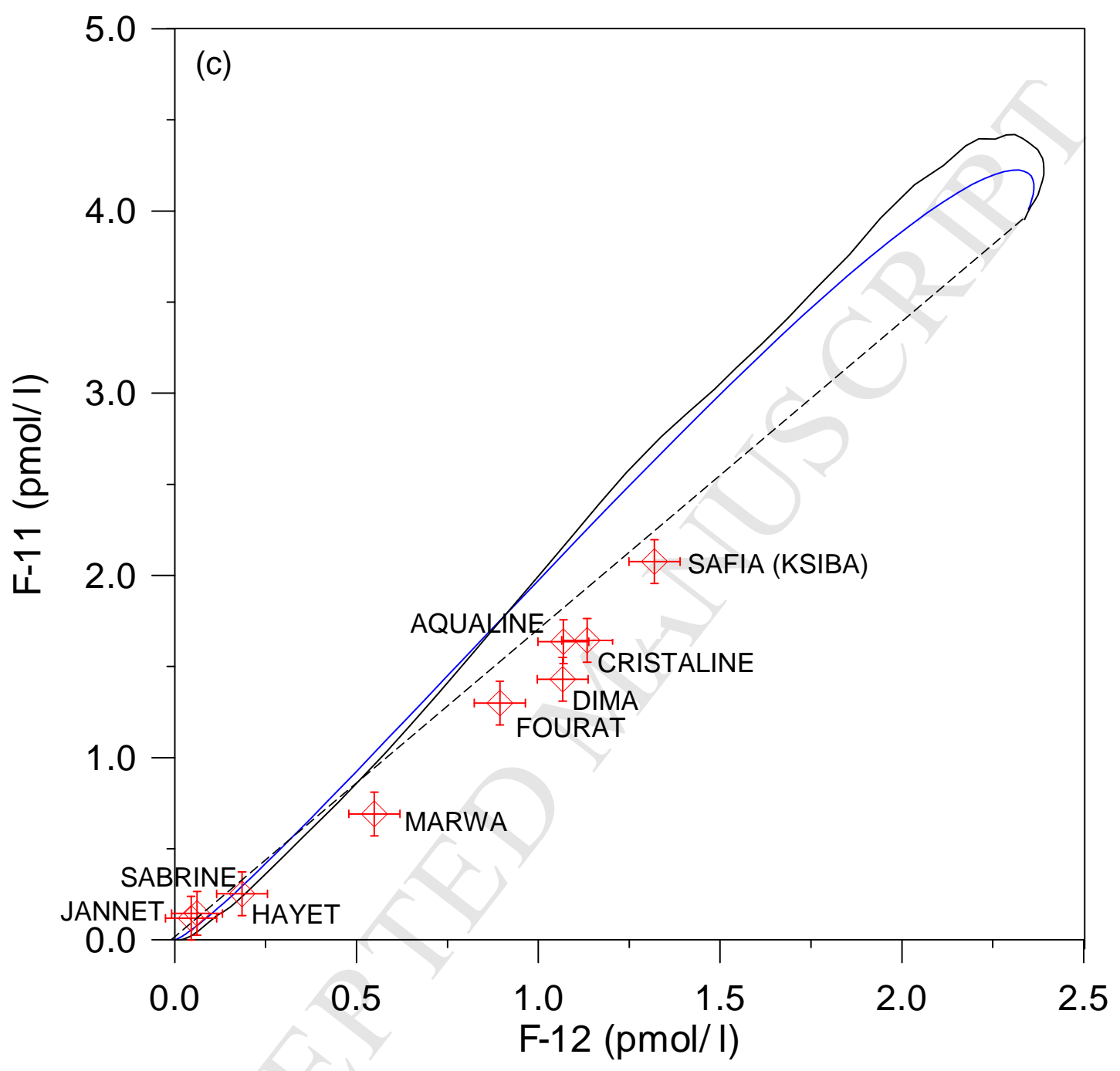

Figure 5c 


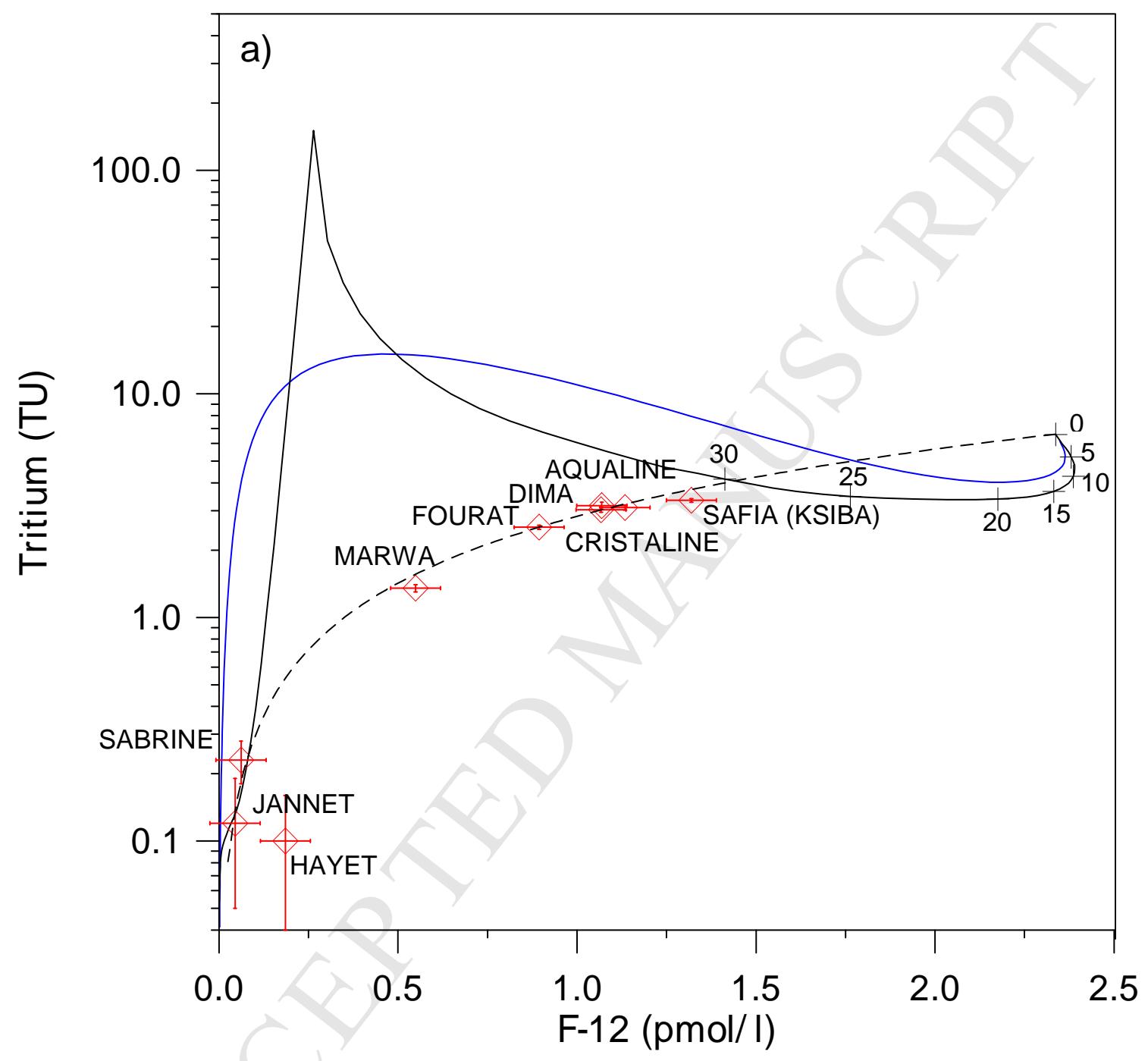

Figure 6a 


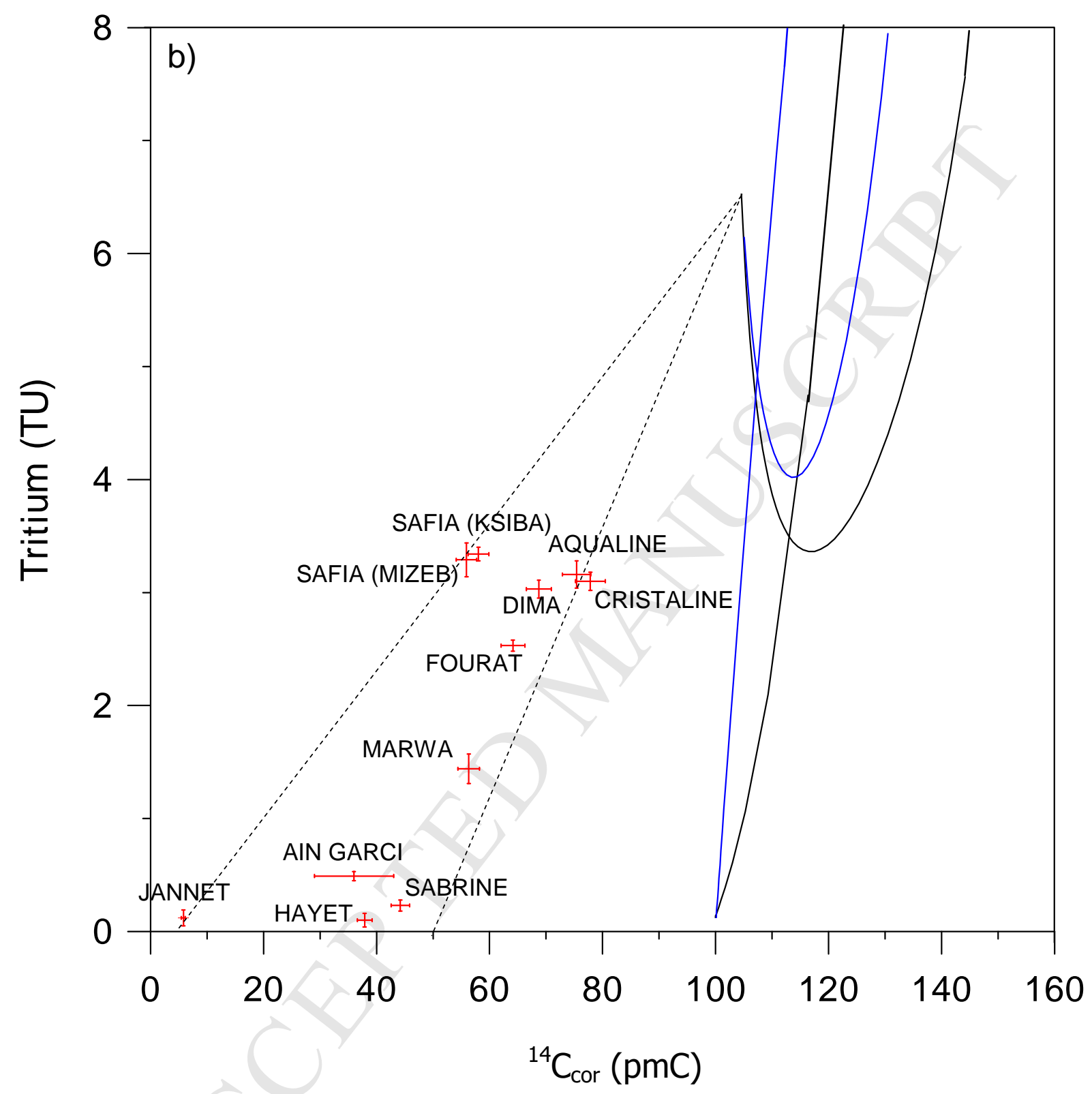

Figure 6b 


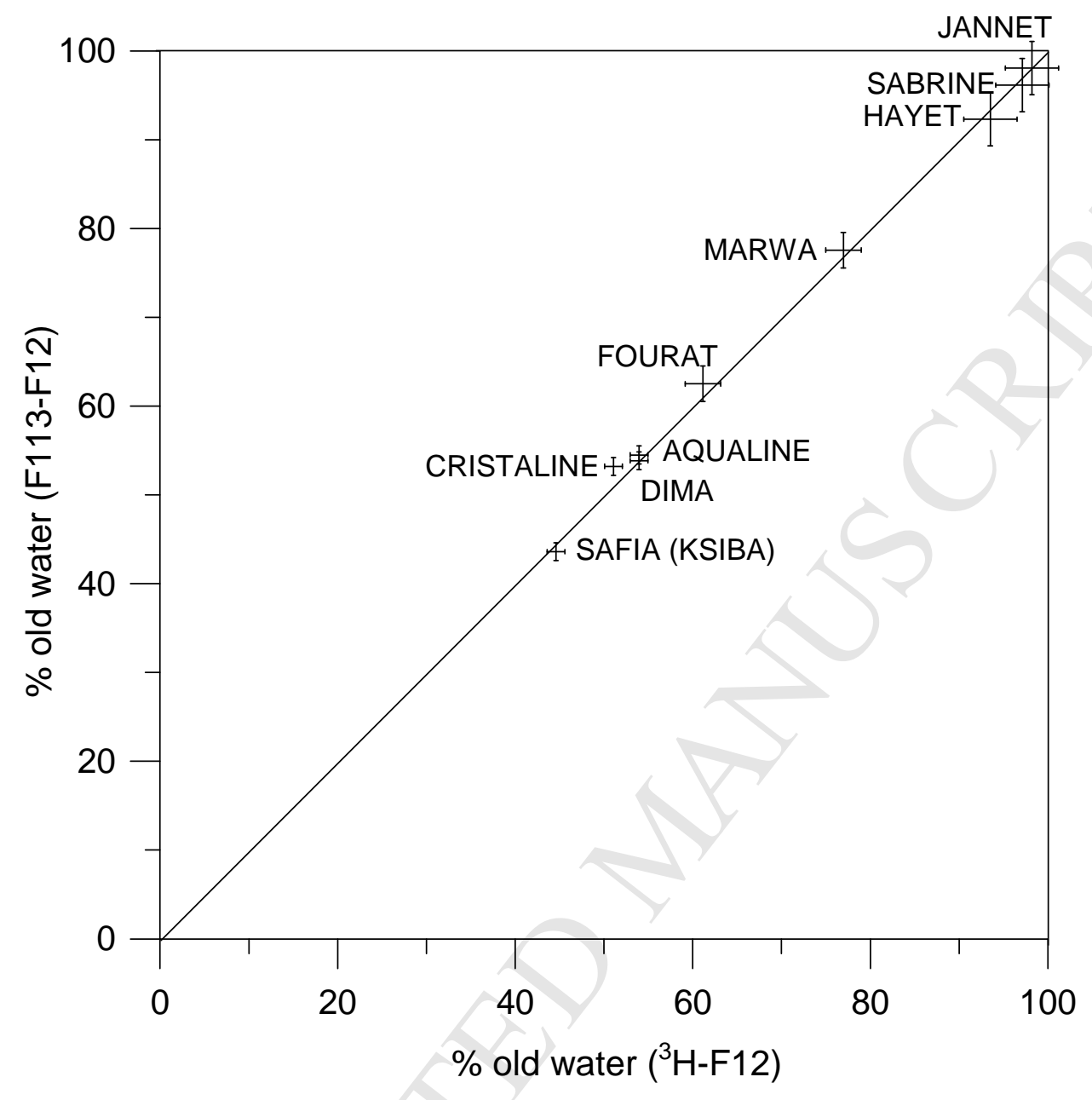

Figure 7 


\section{ACCEPTED MANUSCRIPT}

${ }^{3} \mathrm{H}-{ }^{3} \mathrm{He}, \mathrm{CFCs}, \mathrm{SF}_{6}$ and ${ }^{14} \mathrm{C}$ were analyzed in commercial mineral groundwaters of Tunisia

All studied groundwaters are a mixture of modern rainwater with old groundwaters

Radiocarbon ages of these old groundwaters are in the range 5000-20000 years

Most groundwaters have renewal times between 50 years and several centuries 